\title{
Effects of Cooking on Levels of PCBs in the Fillets of Winter Flounder (Pseudopleuronectes americanus)
}

T. M. Poston

G. S. Durell(a)

G. Koczwara ${ }^{(a)}$

A. M. Spellacy ${ }^{(a)}$

August 1995

\section{DISCLAIMER}

This report was prepared as an account of work sponsored by an agency of the United States Government. Neither the United States Government nor any agency thereof, nor any of their bility for the accuracy, comply, express or implied, or assumes any legal liability or responsibility for the accuracy, completeness, or usefulness of any information, apparatus, product, or process disclosed, or represents that its use would not infringe privately owned rights. Refermanufacturer, or otherwise does not necessarily process, or service by trade name, trademark, mendation, or favoring by the United and opinions of authors expressed htates Government or any agency thereof. The views United States Government or any agency thereof.

Prepared for the

U.S. Environmental Protection Agency

under a Related Services Agreement

with the U.S. Department of Energy

Contract DE-AC06-76RLO 1830

Pacific Northwest Laboratory

Richland, Washington 99352

(a) Battelle Ocean Sciences, Duxbury, Massachusetts. 


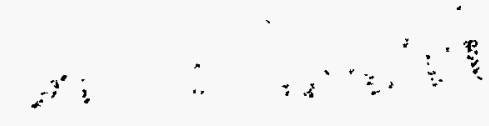




\section{DISCLAIMER}

Portions of this document may be illegible in electronic image products. Images are produced from the best available original document. 
The Pacific Northwest Laboratory and Battelle Ocean Sciences performed a study to determine the effect of cooking on polychlorinated biphenyl (PCB) levels in the fillets of winter flounder (Pseudopleuronectes americanus). Broiling, pan frying, and deep frying in oil were tested on fillets from 21 fish collected from New Bedford Harbor, Massachusetts, on February 21, 1991. The evaluation involved estimating the change in PCB concentrations using a mass-balance approach that factored the change in fillet weight resulting from cooking with the changes in PCB concentration expressed on a precooked wet-weight basis.

Deep frying in oil resulted in a $47 \%$ reduction in total PCB levels in fillet tissue. Additionally, deep frying caused a $40 \%$ reduction in fillet mass. Pan frying and broiling resulted in statistically insignificant increases in total PCB levels of $15 \%$ and $17 \%$, respectively. Fillet mass reductions resulting from pan frying and broiling were $7 \%$ and $15 \%$, respectively. The effects of cooking on 18 individual congeners generally paralleled the results observed for total PCB. All 18 congeners were significantly reduced by deep frying. Congener $\mathrm{Cl}_{2}(08)$ also was significantly reduced by either pan frying or broiling. Congeners $\mathrm{Cl}_{5}(105)$ and $\mathrm{Cl}_{5}(118)$ showed apparent significant increases in concentrations following pan frying. Congeners $\mathrm{Cl}_{5}(105), \mathrm{Cl}_{5}(118)$, and $\mathrm{Cl}_{6}(138)$ showed significant increases in concentration following broiling. 


\section{CONTENTS}

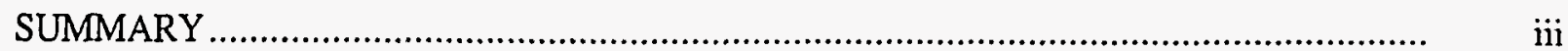

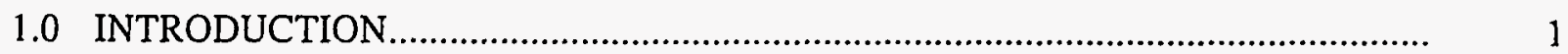

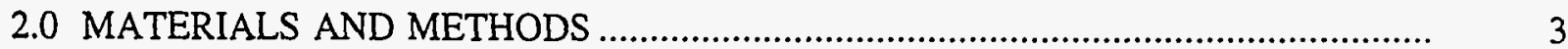

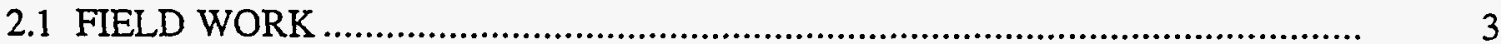

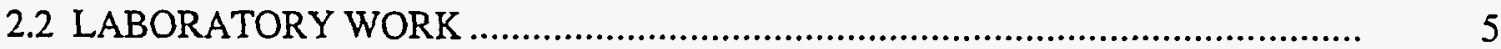

2.2.1 Initial Preparation and Cooking ..................................................... 6

2.2.2 Extraction and Preparation for Analysis..............................................

2.2.3 Instrumental Analysis ....................................................... $\quad 8$

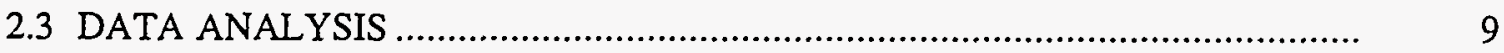

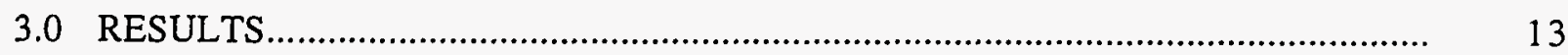

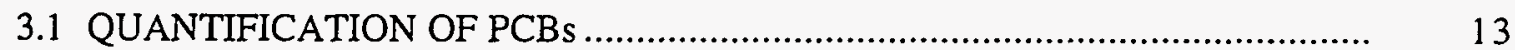

3.2 EFFECTS OF COOKING ON PCB LEVELS....................................................... 16

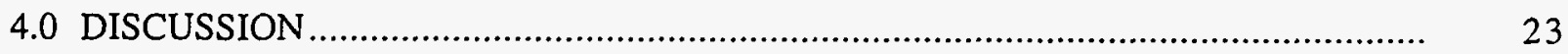

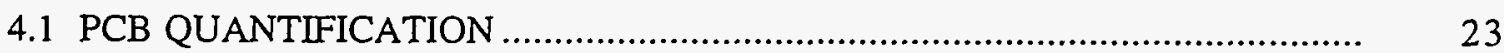

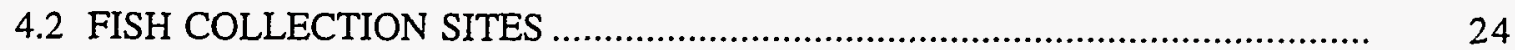

4.3 EFFECTS OF COOKING ON PCB LEVELS.................................................... 24

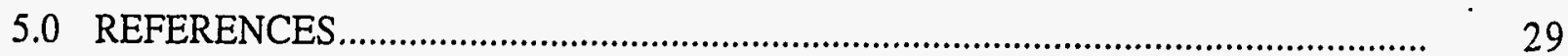

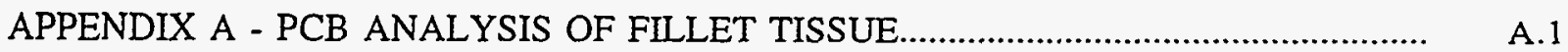

APPENDIX B - QUALITY ASSURANCE AND QUALITY CONTROL ........................... B. B 


\section{FIGURE}

1 New Bedford Harbor Area Map with Approximate Location of

Winter Flounder Sample Collection.

\section{TABLES}

1 PCB Analysis Parameters and Their Respective Detection

Limits

2 Estimated Age of Winter Flounder Based on Length.

Winter Flounder Samples.

4 Analysis of Variance of Fractional Change in Fillet

Weight by Cooking Treatment.

5 Mean Fractional Decreases in Fillet Weight by Section and Cooking Treatment.

6 Three-Way Analysis of Variance of Transformed Fractional

Difference in Total PCB Levels in Cooked Winter Flounder.

7. Fractional Change in Total PCB Levels Resulting from

Cooking Based on Transformed Data

8 Analysis of Variance of Cooking Treatments for Specific

Congeners in Fillets of Winter Flounder.

9 Students $t$ Test for Testing Significance of Cooking on Specific Congeners in Deep-Fried Fillets of Winter

Flounder.

10 Students $t$ Test for Testing Significance of Cooking on Specific Congeners in Pan-Fried Fillets of Winter

Flounder

11 Students $t$ Test for Testing Significance of Cooking on Specific Congeners in Broiled Fillets of Winter Flounder

12 Regression Analysis of PCB Concentrations Against Changes in Weight, Precooking Weight, and Recovery of the Internal Standard DBOFB 


\subsection{INTRODUCTION}

The consumption of contaminated seafood has been shown to be a significant pathway for human exposure to polychlorinated biphenyls (Cordle et al. 1982). Human health exposure assessments currently conducted by the U.S. Environmental Protection Agency (EPA) often assume that levels of contaminants in edible tissue of fish remain the same-after preparation and cooking. This assumption may lead to overestimation or underestimation of risk because a particular cooking method may remove or transform toxic constituents in the tissue by thermal decomposition, volatilization, dissolution in aqueous tissue fluids or lipids that drip off the tissue, or extraction into cooking oil during preparation.

Polychlorinated biphenyls (PCBs) are of particular interest because of their ubiquitous presence in the environment (including commonly consumed seafood), and their documented deleterious environmental and health effects. Although concentration levels and the fate and effects of PCBs in marine resources have been investigated in many earlier studies (e.g., Courtney and Denton 1976; Connolly 1991; Eisenberg et al. 1980; Rusek 1989; Pruell et al. 1988; Kolek and Ceurvels 1981), little information is available on the effects of cooking on PCB levels in seafood. Zabik et al. (1979) attempted to assess the effects of baking, broiling, and microwave preparation on PCB levels in lake trout. The results were inconclusive, and they suggested that cooking did not appear to significantly affect $\mathrm{PCB}$ levels in trout. Others have reported both significant decreases and significant increases in PCB levels following cooking of fish muscle (Smith et al. 1973; Cichy et al. 1979; Zabik et al. 1982; Puffer and Gossett 1983; Armbruster et al. 1989; Trotter et al. 1989).

The objective of this study was to quantify the effect of preparation and cooking on incurred PCB contaminants in the edible portion of seafood. The study focused on the effects of three different cooking methods (broiling, deep frying in oil, and pan frying) on concentrations of specific PCB congeners commonly found in fillets of winter flounder (Pseudopleuronectes americanus). The work plan was developed by the Environmental Protection Agency, Exposure Assessment Group in the Office of Research and Development, Washington, D.C.; Pacific Northwest Laboratory (PNL), (a) Richland, Washington; and Battelle Ocean Sciences (BOS), ${ }^{(b)}$ Duxbury, Massachusetts. Sample processing and analysis were performed by Battelle Ocean Sciences.

This report contains four sections. In Section 2, the materials and methods involved in the field and laboratory work and in the data analysis are presented. The results of the study are summarized in Section 3, and Section 4 provides a further discussion of the analytical results. All PCB values are

(a) PNL is operated for the U.S. Department of Energy by Battelle Memorial Institute.

(b) BOS is a component of Battelle Columbus Laboratories, Battelle Memorial Institute. 
expressed as nanograms of PCB per precooked wet fillet weight in grams to accommodate the massbalance approach used to evaluate the data. 


\subsection{MATERIALS AND METHODS}

The winter flounder used for this study were collected in New Bedford Harbor, Massachusetts. The fish were prepared and cooked by three cooking methods: pan frying, broiling, and deep frying. Fillet tissues from each fish were analyzed for total PCB concentrations and 18 specific PCB congeners, before and after cooking (Table 1). The total PCB concentrations in the samples also were determined based on summation and ratios for 17 of the identified congeners. Congener $\mathrm{Cl}_{7}$ (170) was excluded from this determination because sometimes a low-level laboratory interferant coeluted with this congener in the instrumental analysis. The PCB data were generated and compiled with procedures used in the National Status and Trends Mussel Watch Program (Battelle 1990).

\subsection{FIELD WORK}

Winter flounder were collected on February 21, 1991. The intent was to collect 25 fish in the $25-$ to $35-\mathrm{cm}$ range to maximize the chances of selectively collecting 3-year-old fish. Winter flounder that hatch in New Bedford Harbor stay in the estuary for approximately 3 to 4 years before beginning their annual migration pattern. (a) Four-year-old fish generally migrate out of the area in the spring and are often of commercial fishing size (larger than $30 \mathrm{~cm} \mathrm{long).} \mathrm{Selecting} \mathrm{3-year-old}$ (rather than older) fish increases the chances of the fish having spent all their lives in the New

Bedford Harbor area. Age classification was determined by size, based on information obtained from the Massachusetts Division of Marine Fisheries, and is specific to the Buzzards Bay region (Table 2).

Twenty-one winter flounder were caught by otter trawl. Using polyethylene gloves, researchers removed the live fish from the net and placed them on ice in a thoroughly cleaned cooler. At the end of the day, the fish were transported on ice to the laboratory for storage and processing.

The fish were caught outside the New Bedford Harbor hurricane barrier, and between the hurricane barrier and Clarks Point (Figure 1), in an area roughly $3 \mathrm{~km}$ long and $1.5 \mathrm{~km}$ wide. This area is within what is commonly referred to as Restricted Area II, the area north of Ricketsons and Wilbur Points and outside the hurricane barrier. Area II is closed to the taking of bottom-feeding finfish (including winter flounder) and lobster.

(a) Telephone conversation between G. Durell (BOS) and A. Kolek and A. Howell, Massachusetts Division of Marine Fisheries, Boston, Massachusetts. 
TABLE 1. PCB Analysis Parameters and Their Respective Detection Limits

Analyte Identification

\begin{tabular}{|c|c|c|}
\hline$\underline{\mathrm{PCB}}$ & Congener & Cl Substitution \\
\hline $\mathrm{Cl}_{2}$ & $(08)$ & $2,4^{\prime}$ \\
\hline $\mathrm{Cl}_{3}$ & (18) & $2,2 ', 5$ \\
\hline $\mathrm{Cl}_{3}$ & (28) & $2,4,4^{\prime}$ \\
\hline $\mathrm{Cl}_{4}$ & (44) & $2,2^{\prime}, 3,5^{\prime}$ \\
\hline $\mathrm{Cl}_{4}$ & $(52)$ & $2,2^{\prime}, 5,5^{\prime}$ \\
\hline $\mathrm{Cl}_{4}$ & (66) & $2.3^{\prime}, 4.4^{\prime}$ \\
\hline $\mathrm{Cl}_{5}$ & $(101)$ & $2,2^{\prime}, 4,5,5^{\prime}$ \\
\hline $\mathrm{Cl}_{5}$ & $(105)$ & $2,3,3^{\prime}, 4,4^{\prime}$ \\
\hline $\mathrm{Cl}_{5}$ & (118) & $2,3^{\prime}, 4,4^{\prime}, 5$ \\
\hline $\mathrm{Cl}_{6}$ & $(128)$ & $2,2^{\prime}, 3,3^{\prime}, 4,4^{\prime}$ \\
\hline $\mathrm{Cl}_{6}$ & (138) & $2,2^{\prime}, 3,4,4^{\prime}, 5$ \\
\hline $\mathrm{Cl}_{6}$ & (153) & $2,2^{\prime}, 4,4^{\prime}, 5,5^{\prime}$ \\
\hline $\mathrm{Cl}_{7}$ & $(170)$ & $2,2^{\prime}, 3,3^{\prime}, 4,4^{\prime}, 5$ \\
\hline $\mathrm{Cl}_{7}$ & $(180)$ & $2,2^{\prime}, 3,4,4^{\prime}, 5,5^{\prime}$ \\
\hline $\mathrm{Cl}_{7}$ & $(187)$ & $2,2^{\prime}, 3,4^{\prime}, 5,5^{\prime}, 6$ \\
\hline $\mathrm{Cl}_{8}$ & (195) & $2,2^{\prime}, 3,3^{\prime}, 4,4^{\prime}, 5,6$ \\
\hline $\mathrm{Cl}_{9}$ & (206) & $2,2^{\prime}, 3,3^{\prime}, 4,4^{\prime}, 5,5^{\prime}, 6$ \\
\hline $\mathrm{Cl}_{10}$ & (209) & $100 \%$ Substitution \\
\hline
\end{tabular}

\begin{tabular}{cc}
\multicolumn{2}{c}{ Detection Limit } \\
ng/g, & ng/g. \\
dry wt. (a) & wet wt. (b)
\end{tabular}

5.75

1.15

$1.29 \quad 0.26$

0.67

0.13

1.49

0.30

0.97

0.19

1.47

0.29

1.16

0.23

1.16

0.23

1.19

0.24

0.65

0.13

1.96

0.39

2.39

0.48

0.49

0.10

0.96

0.19

1.72

0.34

0.56

0.11

0.86

0.17

1.18

0.24

(a) Determined using oyster tissue (Battelle 1991).

(b) Calculated by multiplying dry-weight detection limit by 0.2 .

TABLE 2. Estimated Age of Winter Flounder Based on Length

\begin{tabular}{cl} 
Age,_(yr) & Length. $(\mathrm{cm})$ \\
2 & 13 to 25 \\
3 & 22 to $35(\mathrm{a})$ \\
4 & 27 to 42 \\
\hline
\end{tabular}

(a) Three-year age-class average is $27.5 \mathrm{~cm}$. 


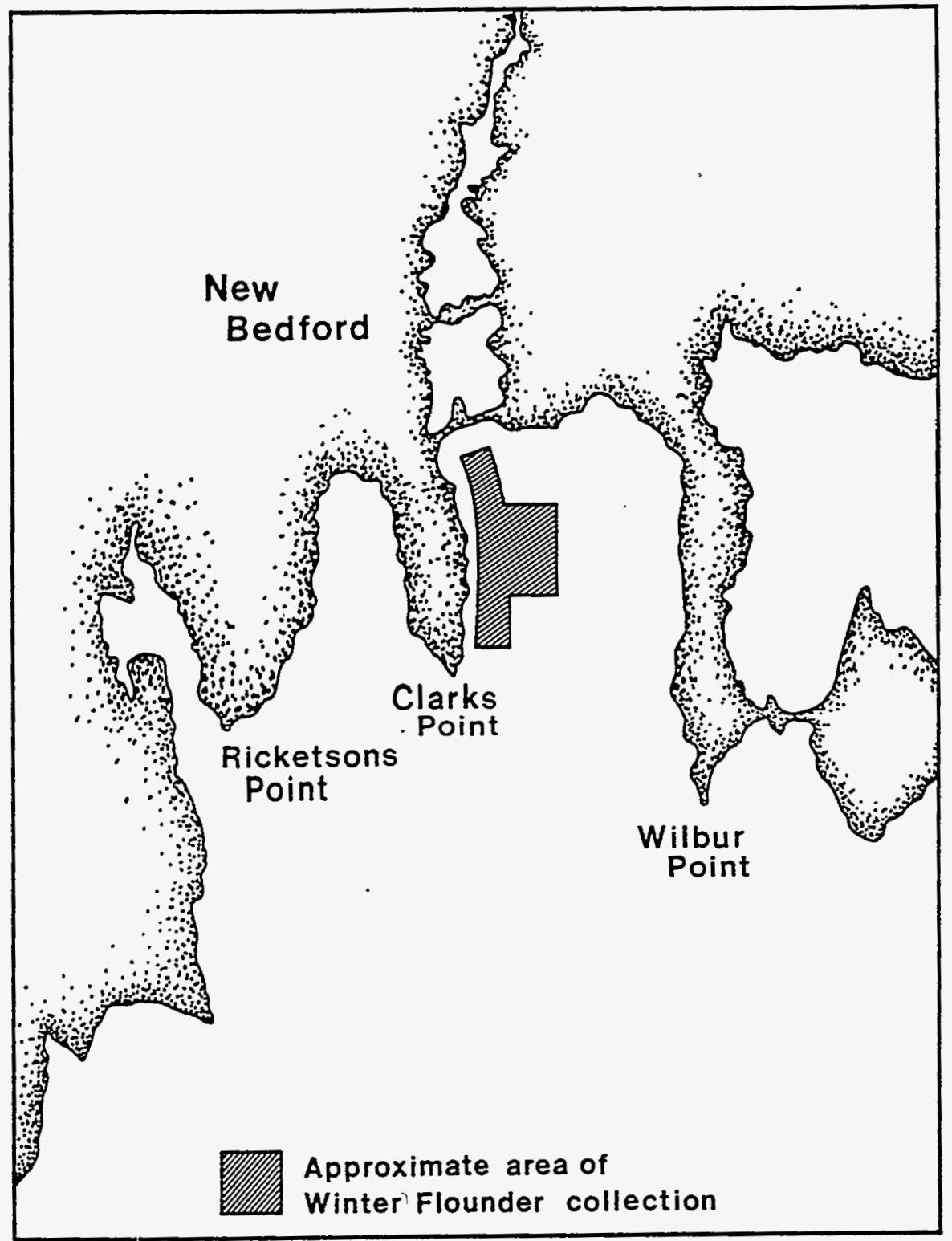

FIGURE 1. New Bedford Harbor Area Map with Approximate Location of Winter Flounder Sample Collection

\subsection{LABORATORY WORK}

The laboratory work consisted of the initial processing of the samples (filleting and cooking), sample processing for analysis (e.g., extraction, purification), and instrumental analysis. The initial processing of all fish was completed in one day. Sample processing for analysis, the instrumental analysis, and the data reduction were performed in two steps: 1) a pilot study in which five fish, representing the whole range of age/size of the 21 fish caught, were analyzed; and 2) the definitive study in which the remaining fish were analyzed. 


\subsubsection{Initual Preparation and Cooking}

Winter flounder were stored whole on ice and processed within $24 \mathrm{~h}$ after collection. The initial processing involved filleting the fish, sectioning the fillets, and cooking the fillet sections according to one of three "treatments": deep frying, pan frying, or broiling. The cooked flesh was homogenized and stored frozen $\left(-20^{\circ} \mathrm{C}\right)$ until extraction could begin. Measurements of whole fish length, weight, and fillet section weight before and after cooking were made and recorded during the initial sample preparation.

The sample processing yielded one carcass sample for each fish, and oil/drippings samples from each of the deep-frying and pan-frying treatments. The broiling did not generate enough drippings to collect. Fish carcass and oil/drippings samples were archived at $-20^{\circ} \mathrm{C}$.

\section{Filleting and Sectioning}

Each fish was assigned a unique laboratory identification code when removed from the cooler for processing (e.g., WF01 for winter flounder \#1). Weight and fork length (tip of snout to fork in tail) were recorded for all fresh fish before filleting. The fish were examined for external abnormalities (e.g., fin rot and tumors).

During the filleting, care was taken not to disrupt the viscera. All materials coming in contact with the sample (e.g., aluminum foil, sample jars, filleting knife, cutting board, and various laboratory utensils) were cleaned with soap and distilled water, then rinsed with methanol and dichloromethane. Glassware was also baked and rinsed with solvent between samples. Polyethylene gloves were worn at all times when handling fish or tissue.

The fish was removed from the cooler and placed on aluminum foil. A sharp stainless steel filleting knife was used to fillet the fish into two skinfree fillets, one top and one bottom fillet. To reduce bias resulting from the choice of fillet, alternating fillets (top and bottom) were selected for precooking and cooking treatments. The fillet used for background/untreated PCB determination was placed in a prelabeled glass jar immediately after filleting. The fillet used for cooking was placed on a precleaned marble cutting board and was cut on a dorsal-ventral plane into three subsamples of approximately equal size. The anterior (nearest the head) section was Section I, the middle section was Section II, and the posterior section was Section III. The fish subsamples were then placed on a sheet of precleaned aluminum foil that had been prelabeled to identify the fish, fillet (top or bottom), fillet section, and treatment. The carcass, including viscera, was wrapped in precleaned aluminum foil, placed in a prelabeled Ziploc bag, and frozen at or below $-20^{\circ} \mathrm{C}$ should later analysis be of interest.

The choice of fillet used for cooking alternated between top and bottom to reduce bias. For 10 of the 21 fish, the top fillet was used as the treatment fillet; for the other 11 fish, the bottom fillet was 
used. Similarly, attempts were made to reduce bias by alternating the section of the treatment fillet (Section I, II, or III) used for the three cooking treatments. . An equal number of the three different sections were used for each cooking treatment; i.e., seven were of Section I, seven of Section II, and seven of Section III from the 21 fish used for each of the three cooking methods.

\section{Cooking and Homogenizing}

During the cooking of the fish, attempts were made to reproduce restaurant- and home-kitchen cooking and serving techniques. Optimal processing and cooking methods and conditions were determined before processing the fish caught for this study, using store-bought winter flounder of comparable size. The fish were cooked thoroughly but not overcooked. Pre- and post-cooking weights of the treatment sections were recorded to determine weight loss and precooking equivalent weights. Additionally, moisture and lipid content was determined on all background (raw) samples.

Fish samples for deep frying were cooked for approximately $1 \mathrm{~min}$ in $200 \mathrm{~mL}$ of pure vegetable oil in a fryer that had been preheated for $5 \mathrm{~min}$. Fish samples for pan frying were cooked for approximately 1 min per side in 1 tablespoon of lightly salted butter in a 9-in. "non-stick" frying pan that had been preheated on a portable electric range. Fish samples for broiling were cooked for approximately 2 min on a broiling pan in an oven that had been preheated for broiling. The fryer, the pans, and all utensils that came in contact with the fish were thoroughly cleaned before processing the first fish and between the processing of each succeeding fish. Cleaning involved washing the cooking apparatus with soap and water, then rinsing with methanol and allowing to air dry. Fresh cooking oil was used for each fish. The fish subsamples were handled as during normal cooking and serving. Cooked fillet subsamples were not blotted dry; however, excess oil was allowed to drip off. The cooked subsamples were placed in prelabeled glass jars for storage.

The cooked samples were homogenized within $1 \mathrm{~h}$ of filleting and cooking with an Omni homogenizer and were stored frozen at or below $-20^{\circ} \mathrm{C}$ until sample extraction.

\subsubsection{Extraction and Preparation for Analysis}

Samples were thawed, and approximately 5 to $25 \mathrm{~g}$ of tissue homogenate was removed and placed in a Teflon jar for extraction. The subsample was fortified with approximately $60 \mathrm{ng}$ of the surrogate compound dibromooctafluorobiphenyl (DBOFB). Matrix-spike samples were fortified with approximately $50 \mathrm{ng}$ of each of the PCB congener analytes and approximately $60 \mathrm{ng}$ of the surrogate compound. Sodium sulfate was added to absorb water. The sample homogenate was macerated twice for $2 \mathrm{~min}$ with a Tissuemizer, using dichloromethane as the extraction solvent. The sample was centrifuged between extractions and the extract decanted. After the two 
maceration/extraction steps, dichloromethane was added to the sample and the jar was shaken for approximately $30 \mathrm{~min}$. Again, the sample was centrifuged and the extracts combined.

The extract was passed through $20 \mathrm{~g}$ of alumina for preliminary cleanup and concentrated using a Kuderna-Danish apparatus, followed by gentle evaporation with nitrogen gas. The extract was then purified by gel permeation high-performance liquid chromatography (HPLC). The HPLC analyte fraction was concentrated by nitrogen evaporation, solvent exchanged for isooctane, and reduced to a final volume of approximately $200 \mu \mathrm{L}$. The sample was then fortified with approximately $50 \mathrm{ng}$ of the recovery internal standard tetrachloro-m-xylene (TCMX), and submitted for analysis by gas chromatography/electron capture detection (GC/ECD).

\subsubsection{Instrumental Analvsis}

The samples were analyzed using a Hewlett-Packard Model 5890A gas chromatograph with a $63 \mathrm{Ni}$ electron-capture detector (Battelle 1990). The analytes were separated chromatographically using a $30-\mathrm{m} \times 0.25-\mathrm{mm}$-inner-diameter fused-silica capillary column, with a $0.25-\mu \mathrm{m}$ stationary phase (95\% methylsilicone and 5\% phenylsilicone) film thickness (J\&W Scientific, Folsom, California). Sample injection volume was $2 \mu \mathrm{L}$. Hydrogen was used as the carrier gas at a flow rate of approximately $1.5 \mathrm{~mL} / \mathrm{min}$. The detector makeup gas was $9.5 \%$ argon and $5 \%$ methane at a flow rate of approximately $40 \mathrm{~mL} / \mathrm{min}$. Injector and detector temperatures were $280^{\circ} \mathrm{C}$ and $325^{\circ} \mathrm{C}$, respectively. The $\mathrm{GC}$ temperature program was as follows: a 1-min hold at $60^{\circ} \mathrm{C}, 60$ to $150^{\circ} \mathrm{C}$ at $15^{\circ} \mathrm{C} / \mathrm{min}, 150$ to $210^{\circ} \mathrm{C}$ at $1^{\circ} \mathrm{C} / \mathrm{min}, 210$ to $280^{\circ} \mathrm{C}$ at $10^{\circ} \mathrm{C} / \mathrm{min}$, and a $10-\mathrm{min}$ hold at $280^{\circ} \mathrm{C}$.

All chromatographic data were acquired, reduced, and stored using the Beckman PeakPro chromatography software operating on a Hewlett-Packard 1000 A-Series minicomputer. The GC/ECD quantification files were transferred to a personal computer for subsequent manipulation of the data.

The PCB congener concentration data were determined in nanograms per gram on a raw wetweight basis. The extraction sample wet weights were corrected to raw wet weight for the treatment samples, using the pre- and post-cooking sample weight ratios from the same fish and treatment section (see Appendix A). The extraction sample wet weight was obtained directly for the untreated samples. To determine the concentration of PCB in the cooked fillet, simply multiply the precooked value (Tables A.2 through A.4) by the ratio of the cooked weight to the precooked weight (Table A.6).

The samples were quantified relative to the surrogate compound DBOFB. The recovery internal standard TCMX was used to determine surrogate recoveries in the samples. Four types of PCB data are reported for each field sample (Appendix A): 1) the concentrations of each of the 18 
PCB congeners, 2) the sum of the concentrations of the 18 PCB congeners, 3) the total PCB concentration based on the ratio of the sum of the concentrations of the $18 \mathrm{PCB}$ congeners to the total PCB in an equal mix of Aroclors 1242 and 1254, and 4) the total PCB concentration based on the ratio of the sum of the concentrations of $17 \mathrm{PCB}$ congeners [excluding $\mathrm{Cl}_{7}(170)$ ] to the total $\mathrm{PCB}$ in an equal mix of Aroclors 1242 and 1254.

The PCB congeners were quantified using individual response factors for each analyte. The response factors were determined from a three-point calibration curve analyzed with each set of no more than 20 samples. To calculate the total PCB concentration, the average concentration of the 18 PCB congeners in a "total PCB-mix" was determined for a 1:1 mix of Aroclors 1242 and 1254. This Aroclor composition is the approximate composition of the PCBs in the New Bedford Harbor sediment where the fish were collected (EPA, Narragansett, Rhode Island, personal communication). The congener composition was determined by combining approximately $100 \mathrm{ng}$ of the surrogate compound and approximately $1 \mu \mathrm{g}$ each of Aroclors 1242 and 1254, diluting to approximately 1000 $\mu \mathrm{L}$ with hexane, and performing triplicate analyses. The ratio of the sum of concentrations of the 18 congeners to total $\mathrm{PCB}$ concentration was then determined and subsequently used in calculating the total PCB concentration in the winter flounder samples.

\subsection{DATA ANALYSIS}

All data analysis was conducted with Statview $512^{+}$, a statistical software package (Abacus Concepts 1986). Data initially were analyzed as total PCB levels based on estimated levels for 17 congeners. The data were used to determine the fractional change in PCBs as a result of cooking (derived from Skea et al. 1979):

$$
F=\left[\left(C_{r} \times M_{r}\right)-\left(C_{c} \times M_{c}\right)\right] /\left(C_{r} \times M_{r}\right)
$$

$$
\text { where } \begin{aligned}
F & =\text { the fractional change in PCBs } \\
C_{r} & =\text { concentration of PCBs in raw fillet } \\
M_{r} & =\text { mass of raw fillet } \\
C_{C} & =\text { concentration of PCBs in cooked fillet } \\
M_{C} & =\text { mass of cooked fillet. }
\end{aligned}
$$

The data, which had both positive and negative values, were transformed by raising the fractional change to the natural logarithm (ln; i.e., $e^{\mathrm{F}}$ ). This transformation was necessary because of the large range in PCB concentrations and associated high variability. A three-way analysis of 
variance (ANOVA) was performed to evaluate differences of cooking treatment, section, and fillet on the transformed data. A oneway ANOVA was performed on treatment effects, and differences between cooking treatments were evaluated with Fisher's Least Significant Differences (LSD) test.

The transformed fractional data also were tested against the null hypothesis $\left(\mathrm{H}_{\mathrm{O}}\right)$ of no difference by conducting two-tailed $\mathrm{t}$ tests.

The null hypothesis was

$$
\mathrm{H}_{0}: e^{\mathrm{F}}=1 \text { (i.e., transformed } e^{0}=1 \text { ) }
$$

The alternative hypotheses $\left(\mathrm{H}_{\mathrm{a}}\right)$ were

$$
\begin{gathered}
\mathrm{H}_{\mathrm{a}}: \quad e^{\mathrm{F}}<1, \text { or } \\
e^{\mathrm{F}}>1
\end{gathered}
$$

where $F$ represents the change in the transformed treatment sample mean and the transformed control (uncooked) mean.

The same approach was used to evaluate the effects of cooking on individual congeners. Cases in which a congener was at less than detection levels in the raw tissue were deleted from the data sets. When levels in both the cooked and the raw fillet were below detection, the fractional change was recorded as $0 \%\left(e^{0.00}=1.000\right)$. When a congener was quantified in the raw fillet but below detection in the cooked fillet, the fractional change was entered as $100 \%$, or $2.718\left(e^{1.00}=2.718\right)$. This modification biased the results low (i.e., it will overestimate PCB reduction) because, in the majority of these cases, the cooking treatment resulted in a less-than-detectable concentration when the raw sample was quantifiable. A small reduction in congener concentration may have resulted in a less-than-detectable amount, but not complete removal. This reanalysis involved congeners $\mathrm{Cl}_{2}(08)$, $\mathrm{Cl}_{3}$ (18), $\mathrm{Cl}_{8}$ (195), $\mathrm{Cl}_{9}$ (206), and $\mathrm{Cl}_{10}$ (209).

Additional analysis of variance was conducted on other experimental factors to determine whether there were differences in cooking effects related to precooked-sample weight, change in subsample weight during cooking, fractional change in subsample weight during cooking, or recovery of the internal standard (DBOFB). Additionally, the relationship between lipid content and PCB concentration was evaluated by regression analysis of the ln-transformed total PCB estimates 
based on 17 congeners. The ln-transformed total PCB levels were compared with fish mass and length by regression analysis to determine whether there was a relationship between age and PCB tissue burden. 



\subsection{RESULTS}

Twenty-one winter flounder, designated WF01 through WF21, were collected and processed for this study. The lengths of the fish ranged from 25 to $42 \mathrm{~cm}$ (Table 3), indicating age classes ranging from 3 to 4 years. The weight of the fish ranged from 223 to $1181 \mathrm{~g}$. All fish appeared healthy, with no external signs (e.g., fin rot or tumors) of environmental effects. Based on the presence of eggs and sperm, it appeared that most of the fish were caught before spring spawning. Regression analyses of ln-transformed total PCB with mass $(P=0.62)$ and length $(P=0.47)$ of the winter flounder were not significant.

Fillet sample size varied considerably because of the variability in the size of the fish (see Appendix A). The experimental design normalized the effects of section location. An analysis of variance was performed to determine whether there were differences in the fillet's raw sample weight, overall change in weight, and fractional change in fillet weight among the three cooking treatments. This analysis was done by section (I, II, or III) and indicated no difference in raw sample weight by treatment or section; however, changes in sample weight resulting from cooking were statistically significant (Table 4; $\mathrm{P}=0.0001$ ).

Deep-fried fillets showed approximately $40 \%$ loss in weight, apparently resulting from loss of water (Table 5). There was less weight loss for pan frying and broiling, and it was more variable. The weight loss averaged approximately $7 \%$ and $15 \%$ for pan frying and broiling, respectively. The moisture content was fairly constant, approximately $80 \%$, for the 21 fish (see Table 3 ). The lipid content was more variable but was in the $10-$ to $20-\mathrm{mg} / \mathrm{g}$ range for most of the uncooked fish. A simple regression analysis between lipid content in control fillets and In-transformed total PCBs showed no significant relationship $\left(P=0.385, R^{2}=0.042\right)$.

The following sections present the results of the laboratory chemical analyses of these fish.

\subsection{QUANTIFICATION OF PCBs}

The results of the triplicate analyses of an equal mix of Aroclors 1242 and 1254 are presented in Appendix A. These data indicate that the $18 \mathrm{PCB}$ congeners used in this study constitute approximately $58 \%$ of the total PCB in a 1:1 mix of Aroclors 1242 and 1254. This relationship was then used to determine the total PCB concentration, as an equal mix of Aroclors 1242 and 1254, in the fish samples. This relationship also was determined using $17 \mathrm{PCB}$ congeners, after excluding $\mathrm{Cl}_{7}(170)$. The 17 congeners make up approximately $57 \%$ of the total PCB [i.e., $\mathrm{Cl}_{7}(170)$ is present 
TABLE 3. Length, Weight, Moisture Content, and Lipid Content of Winter Flounder Samples

\begin{tabular}{|c|c|c|c|c|}
\hline Fish ID & Length $(\mathrm{cm})$ & Weight (g) & Moisture (\%) (a) & Lipid (mg/g wet wt.) $)^{(a)}$ \\
\hline WF01 & 35.0 & 716.7 & 81.7 & 11.2 \\
\hline WF02 & 25.0 & 335.5 & 81.9 & 14.8 \\
\hline WF03 & 27.0 & 240.9 & 79.5 & 15.2 \\
\hline WF04 & 30.0 & 304.3 & 80.7 & 19.8 \\
\hline WF05 & 32.0 & 493.3 & 81.8 & 11.5 \\
\hline WF06 & 34.0 & 573.3 & 83.4 & 13.4 \\
\hline WF07 & 35.0 & 688.2 & 81.7 & 44.7 \\
\hline WF08 & 31.0 & 492.4 & 79.8 & 8.5 \\
\hline WF09 & 30.0 & 298.7 & 79.6 & 10.1 \\
\hline WF10 & 32.0 & 512.3 & 80.7 & 36.9 \\
\hline WF11 & 30.0 & 328.7 & 81.9 & 16.9 \\
\hline WF12 & 27.0 & 252.7 & 79.9 & 24.0 \\
\hline WF13 & 35.0 & 500.7 & 80.9 & 15.0 \\
\hline WF14 & 27.0 & 223.2 & 80.9 & 34.7 \\
\hline WF15 & 28.5 & 326.7 & 81.0 & 8.7 \\
\hline WF16 & 38.0 & 537.2 & 82.2 & $N R^{(b)}$ \\
\hline WF17 & 38.5 & 722.3 & 84.0 & 14.8 \\
\hline WF18 & 37.5 & 658.1 & 83.1 & 11.7 \\
\hline WF19 & 39.0 & 695.3 & 83.8 & 14.9 \\
\hline WF20 & 40.0 & 680.3 & 85.0 & 19.9 \\
\hline WF21 & 42.0 & 1181.2 & 83.3 & 14.4 \\
\hline
\end{tabular}

(a) Moisture and lipid measures taken from the raw fillet.

(b) Not reported, sample lost.

in relatively low proportions in these Aroclors]. Sometimes a low-level laboratory interferant coeluted with $\mathrm{Cl}_{7}(170)$ in the instrumental analysis, which could result in unreliable data for $\mathrm{Cl}_{7}(170)$. Consequently, all statistical analyses for total $\mathrm{PCB}$ were based on the estimated value derived from the 17-congener estimate. Total PCB levels are reported based on all 18 congeners and on the 17 congeners (see Appendix A). As it turned out, the total PCB data for each set of congeners 
TABLE 4. Analysis of Variance of Fractional Change in Fillet Weight by Cooking Treatment

\begin{tabular}{|c|c|c|c|c|c|}
\hline Source & $\underline{\mathrm{df}}$ & Sum of Squares & Mean Square & F-test & $\underline{\mathrm{p} \text { Value }}$ \\
\hline Between treatments & 2 & 1.234 & 0.617 & 121.7 & 0.0001 \\
\hline Within treatments & 60 & 0.304 & 0.005 & & \\
\hline Total & 62 & 1.538 & & & \\
\hline
\end{tabular}

TABLE 5. Mean Fractional Decreases in Fillet Weight by Section and Cooking Treatment

\begin{tabular}{|c|c|c|c|c|}
\hline \multirow[b]{2}{*}{ Section } & \multicolumn{3}{|c|}{ Cooking Treatment } & \multirow[b]{2}{*}{ Total } \\
\hline & Broil & Deep Fry & $\underline{\text { Pan Fry }}$ & \\
\hline \multirow[t]{2}{*}{ I } & 0.162 & 0.379 & 0.064 & 0.202 \\
\hline & & & & $(0.151)^{(a)}$ \\
\hline \multirow[t]{2}{*}{ II } & 0.124 & 0.410 & 0.072 & 0.202 \\
\hline & & & & $(0.164)$ \\
\hline \multirow[t]{2}{*}{ IIl } & 0.173 & 0.416 & 0.084 & 0.224 \\
\hline & & & & $(0.164)$ \\
\hline \multirow[t]{2}{*}{ Total } & $0.153^{(b)}$ & 0.402 (b) & $0.073^{(b)}$ & 0.209 \\
\hline & $(0.079)$ & $(0.083)$ & $(0.045)$ & \\
\hline
\end{tabular}

(a) Standard deviation in parentheses.

(b) Significant at $95 \%$ level of confidence.

were similar because the amount of $\mathrm{Cl}_{7}(170)$ and any $\mathrm{Cl}_{7}(170)$ interference were low relative to the concentrations of other congeners in the fish samples.

PCB concentrations are reported in (ng/g) wet weight, on a precooking-weight basis, for the raw, deep-fried, pan-fried, and broiled fish. Some analytes were reported below the previously determined detection limit (see Table 1), but no analytes were quantified unless the analyst had a high degree of confidence in the identification. A signal-to-noise ratio of approximately 5:1 was generally used as the criterion in analyte identification and quantification, and each individual analyte identification was visually confirmed before the data were accepted.

The 21 fish collected showed a large range in PCB concentrations. Total PCB concentration, based on 17 congeners, ranged from 0.014 to $4.0 \mu \mathrm{g} / \mathrm{g}$ wet weight in the untreated fillet. This range is a concentration difference of more than two orders of magnitude. Three of the 21 fish had PCB 
concentrations in the untreated fillet that exceeded the Food and Drug Administration action limit of $2 \mu \mathrm{g} / \mathrm{g}$ for seafood.

The PCB congener distributions were similar for most of the fish; $\mathrm{Cl}_{5}(118), \mathrm{Cl}_{6}(153)$, and $\mathrm{Cl}_{6}$ (138) were the most abundant of the 18 congeners. The distribution of PCB congeners observed for the fish samples was quite unlike the expected distribution of congeners in an equal mix of Aroclors 1242 and 1254, based on earlier measurements of PCBs in sediments from this area (see Appendix A). The distribution in the fish looked more like the distribution in Aroclor 1254 alone, based on the relative amounts of PCB congeners by levels of chlorination (Alford-Stevens et al. 1986). Most of the lower-molecular-weight $\ddot{P C B}$ congeners of Aroclor 1242 were detected at relatively low concentrations. The PCB congener distribution in fish may be influenced not only by the distribution in sediment that the fish were exposed to, but also by selective metabolism and bioconcentration.

\subsection{EFFECTS OF COOKING ON PCB LEVELS}

The primary objective of this study was to determine the effects of cooking on PCB levels in winter flounder fillets. The data were highly variable and covered two orders of magnitude, necessitating that the data be transformed for statistical analyses. The ln transformation for PCB concentrations ( $\mathrm{ng} / \mathrm{g}$ ) most closely resembled a normal distribution. The distribution of the fractional change data was also skewed; and the transformed fractional change data $\left(e^{\mathrm{F}}\right)$ better represented a normal distribution, particularly for the pan-frying and broiling treatments.

The transformed data were analyzed by a three-way ANOVA for treatment, section, and fillet effects on total PCB (Table 6). In this three-factor ANOVA, only the treatment effects were significant $(a=0.05)$. A one-factor ANOVA of treatments indicated that the differences in cooking treatments between deep frying and either broiling or pan frying were significant (Table 7). The deep-fried fillets showed a $47 \%$ decrease $\left(e^{F}=1.605\right)$ in total PCB levels, which was significantly different from the $17 \%$ and $15 \%$ increases of total PCBs detected in broiled and pan-fried fillets.

The individual cooking results also were tested with two-tailed $t$ tests to determine whether the fractional change resulting from cooking was significantly different from no change, as indicated by a transformed value of $1.00\left(e^{0.00}=1.00\right)$. Values greater than 1.0 indicate a decrease in PCB levels, and values less than 1.0 indicate an apparent increase in PCB levels. The $47 \%$ decrease in the deep-fried fillet was significant; however, the smaller increases in total PCB concentrations for the pan-frying and broiling treatments were not significant $(a=0.05)$. Fisher's Least Significant 
TABLE 6. Three-Way Analysis of Variance of Transformed $\left(e^{\mathrm{F}}\right)$ Fractional Difference in Total PCB Levels in Cooked Winter Flounder

\begin{tabular}{|c|c|c|c|c|c|}
\hline Source & $\underline{\mathrm{df}}$ & Sum of Squares & Mean Square & F-test & P Value \\
\hline Treatment (A) & 2 & 8.106 & 4.053 & 23.849 & 0.0001 \\
\hline Section (B) & 2 & 1.105 & 0.508 & 2.986 & 0.0606 \\
\hline $\mathrm{AB}$ interaction & 4 & 1.425 & 0.356 & 2.096 & 0.0971 \\
\hline Fillet $(C)$ & 1 & 0.298 & 0.298 & 1.753 & 0.1922 \\
\hline $\mathrm{AC}$ interaction & 2 & 0.019 & 0.010 & 0.056 & 0.9456 \\
\hline $\mathrm{BC}$ interaction & 2 & 0.509 & 0.255 & 1.499 & 0.2344 \\
\hline$A B C$ interaction & 4 & 0.873 & 0.218 & 1.248 & 0.2904 \\
\hline Error & 45 & 7.647 & 0.170 & & \\
\hline
\end{tabular}

TABLE 7. Fractional Change in Total PCB Levels Resulting from Cooking Based on Transformed $\operatorname{Data}\left(e^{\mathrm{F}}\right)$

\begin{tabular}{|c|c|c|c|c|c|c|}
\hline \multirow{2}{*}{$\begin{array}{l}\text { Cooking } \\
\text { Treatment }\end{array}$} & \multirow[b]{2}{*}{ Mean $^{(a)}$} & \multirow{2}{*}{$\begin{array}{l}\text { Standard } \\
\text { Deviation }\end{array}$} & \multirow{2}{*}{$\begin{array}{l}\mathrm{t} \text { Test }(\mathrm{b}) \\
\text { (Prob.) }\end{array}$} & \multicolumn{3}{|c|}{ Fisher's LSD Test } \\
\hline & & & & Broil & Deep Fry & Pan Fry \\
\hline Broil & $\begin{array}{c}0.845 \\
(+16.8 \%)\end{array}$ & 0.398 & 0.171 & -- & $0.275^{(d)}$ & 0.275 \\
\hline Deep fry & $\begin{array}{c}1.605 \\
(-47.3 \%)\end{array}$ & 0.475 & 0.0001 & & -- & $0.275^{(d)}$ \\
\hline Pan fry & $\begin{array}{c}0.858 \\
(+15.3 \%) \\
\end{array}$ & 0.457 & 0.089 & & & -- \\
\hline
\end{tabular}
(a) A value of 1.0 indicates no fractional change $\left(e^{\mathrm{F}}=1.00\right)$; the value in parentheses is the percentage change in PCBs from cooking.
(b) Two-tailed t test for transformed fractional change data $\left(e^{\mathrm{F}}=1.00\right), \mathrm{n}=21$.
(c) $\mathrm{LSD}=$ Least Significant Differences.
(d) Indicates significant (95\%) differences between cooking treatments listed under LSD heading and under Cooking Treatment.

Differences test indicated that the deep-frying treatment was significantly different from the panfrying and broiling methods.

Individual congeners were also evaluated for the effects of cooking on congener levels. The initial analysis evaluated only those cases for which quantifiable concentrations of each congener were found in the raw and the cooked fillet (Table 8). The analysis of variance for the three cooking methods was significant for all congeners except $\mathrm{Cl}_{10}$ (209). 
TABLE 8. Analysis of Variance of Cooking Treatments for Specific Congeners in Fillets of Winter Flounder

\begin{tabular}{lcccc} 
& \multicolumn{4}{c}{ ANOVA } \\
\cline { 3 - 4 } Congener & $\begin{array}{c}\text { Transformed } \\
\text { Mean Square }\end{array}$ & df & $\underline{\text { F-Value }}$ & Prob. \\
\cline { 3 - 5 } $\mathrm{Cl}_{2}(08)$ & 3.46 & 32 & 16.91 & 0.0001 \\
$\mathrm{Cl}_{3}(18)$ & 2.39 & 60 & 13.22 & 0.0001 \\
$\mathrm{Cl}_{3}(28)$ & 3.01 & 62 & 15.20 & 0.0001 \\
$\mathrm{Cl}_{4}(44)$ & 1.88 & 61 & 15.60 & 0.0001 \\
$\mathrm{Cl}_{4}(52)$ & 3.32 & 62 & 26.85 & 0.0001 \\
$\mathrm{Cl}_{4}(66)$ & 3.08 & 62 & 12.27 & 0.0001 \\
$\mathrm{Cl}_{5}(101)$ & 3.77 & 62 & 25.50 & 0.0001 \\
$\mathrm{Cl}_{5}(105)$ & 4.40 & 62 & 22.33 & 0.0001 \\
$\mathrm{Cl}_{5}(118)$ & 4.18 & 62 & 21.01 & 0.0001 \\
$\mathrm{Cl}_{6}(128)$ & 4.71 & 59 & 23.71 & 0.0001 \\
$\mathrm{Cl}_{6}(138)$ & 4.25 & 62 & 21.31 & 0.0001 \\
$\mathrm{Cl}_{6}(153)$ & 3.71 & 62 & 18.48 & 0.0001 \\
$\mathrm{Cl}_{7}(170)$ & 4.27 & 62 & 17.76 & 0.0001 \\
$\mathrm{Cl}_{7}(180)$ & 3.90 & 62 & 17.60 & 0.0001 \\
$\mathrm{Cl}_{7}(187)$ & 3.97 & 62 & 23.89 & 0.0001 \\
$\mathrm{Cl}_{8}(195)$ & 3.18 & 51 & 12.02 & 0.0001 \\
$\mathrm{Cl}_{9}(206)$ & 2.67 & 49 & 10.59 & 0.0002 \\
$\mathrm{Cl}_{10}(209)$ & 0.80 & 18 & 3.57 & 0.0522
\end{tabular}

Congeners $\mathrm{Cl}_{2}(08), \mathrm{Cl}_{6}(128), \mathrm{Cl}_{8}(195), \mathrm{Cl}_{9}(206)$, and $\mathrm{Cl}_{10}(209)$ had cases in which either the raw or the cooked fillet had a non-detectable concentration of that specific congener. These cases were not included in the initial congener-specific analysis; consequently, the estimates of cooking effects are biased low for these congeners. The transformed fractional change $\left(e^{F}\right)$ for each congener was tested with two-tailed t tests to determine whether there was a measurable effect due to cooking (see Section 2.3). The null hypothesis was rejected for all 18 congeners tested for deep frying, indicating significant reductions in each congener (Table 9).

Congeners $\mathrm{Cl}_{5}(105)$ and $\mathrm{Cl}_{5}(118)$ had the only significant fractional increases in congener level with $t$ tests $(a=0.05)$ in pan-fried samples (Table 10$)$. Inclusion of the $100 \%$ reduction values for congener $\mathrm{Cl}_{2}(08)$ indicated a significant decrease (about 49\%) for that specific congener. None of the congeners except $\mathrm{Cl}_{2}(08)$ were reduced as a result of pan frying. 
TABLE 9. Students $\mathrm{t}$ Test for Testing Significance of Cooking on Specific Congeners in Deep-Fried Fillets of Winter Flounder.

\begin{tabular}{|c|c|c|c|c|c|c|c|}
\hline Congener & \multicolumn{2}{|c|}{$\begin{array}{l}\text { Transformed } \\
\text { Mean (SD) }\end{array}$} & $\begin{array}{l}\text { \% Mean } \\
\text { Change }\end{array}$ & $95 \% \mathrm{CI}^{(\mathrm{b})}$ & $\underline{\mathrm{df}}$ & $\underline{t}$ Value & Prob. \\
\hline \multicolumn{8}{|c|}{ Quantifiable concentrations in raw and cooked fillets } \\
\hline $\mathrm{Cl}_{2}(08)$ & 2.10 & $(0.29)$ & 74 & 27 & 11 & 12.95 & 0.0001 \\
\hline $\mathrm{Cl}_{3}(18)$ & 1.76 & $(0.35)$ & 57 & 39 & 18 & 9.52 & 0.0001 \\
\hline $\mathrm{Cl}_{3}(28)$ & 1.60 & $(0.35)$ & 47 & 43 & 20 & 7.87 & 0.0001 \\
\hline $\mathrm{Cl}_{4}(44)$ & 1.65 & $(0.28)$ & 50 & 33 & 19 & 8.36 & 0.0001 \\
\hline $\mathrm{Cl}_{4}(52)$ & 1.70 & $(0.32)$ & 53 & 37 & 20 & 9.96 & 0.0001 \\
\hline $\mathrm{Cl}_{4}(66)$ & 1.52 & $(0.55)$ & 42 & 71 & 20 & 4.31 & 0.0003 \\
\hline $\mathrm{Cl} 5(101)$ & 1.67 & $(0.37)$ & 51 & 43 & 20 & 8.36 & 0.0001 \\
\hline $\mathrm{Cl}_{5}(105)$ & 1.57 & $(0.50)$ & 45 & 62 & 20 & 5.19 & 0.0001 \\
\hline $\mathrm{Cl}_{5}(118)$ & 1.54 & $(0.49)$ & 43 & 62 & 20 & 5.03 & 0.0001 \\
\hline $\mathrm{Cl}_{6} \mathrm{128}^{2}$ & 1.81 & $(0.48)$ & 59 & 52 & 19 & 7.59 & 0.0001 \\
\hline $\mathrm{Cl}_{6}(138)$ & 1.59 & $(0.50)$ & 46 & 62 & 20 & 5.50 & 0.0001 \\
\hline $\mathrm{Cl}_{6}(153)$ & 1.60 & $(0.48)$ & 47 & 59 & 20 & 5.72 & 0.0001 \\
\hline $\mathrm{Cl}_{7}(170)$ & 1.63 & $(0.59)$ & 49 & 71 & 20 & 4.91 & 0.0001 \\
\hline $\mathrm{Cl}_{7}(180)$ & 1.76 & $(0.48)$ & 57 & 53 & 20 & 7.33 & 0.0001 \\
\hline $\mathrm{Cl} 7(187)$ & 1.79 & $(0.43)$ & 58 & 47 & 20 & 8.45 & 0.0001 \\
\hline $\mathrm{Cl}_{8}(195)$ & 1.71 & $(0.56)$ & 54 & 64 & 15 & 5.10 & 0.0001 \\
\hline $\mathrm{Clg}(206)$ & 1.97 & $(0.46)$ & 68 & 46 & 13 & 7.94 & 0.0001 \\
\hline $\mathrm{Cl}_{10}(209)$ & 1.66 & $(0.37)$ & 51 & 44 & 5 & 4.35 & 0.0073 \\
\hline \multicolumn{8}{|c|}{ Assumed $100 \%$ reduction when cooked fillet was $<$ detection } \\
\hline $\mathrm{Cl}_{2}(08)$ & 2.28 & $(0.38)$ & 82 & 33 & 16 & 13.92 & 0.0001 \\
\hline $\mathrm{Cl}_{3}(18)$ & 1.85 & $(0.44)$ & 62 & 47 & 20 & 8.92 & 0.0001 \\
\hline $\mathrm{Cl} 4(44)$ & 1.70 & $(0.36)$ & 53 & 42 & 20 & 8.9 & 0.0001 \\
\hline $\mathrm{Clg}(206)$ & 2.13 & $(0.51)$ & 76 & 47 & 17 & 9.39 & 0.0001 \\
\hline $\mathrm{Cl}_{10}(209)$ & 1.81 & $(0.52)$ & 59 & 56 & 6 & 4.11 & 0.0063 \\
\hline
\end{tabular}

\footnotetext{
(a) Transformation was $e^{\mathrm{F}}$, where $e$ is the base of the ln and $\mathrm{F}$ is the fraction change; (SD) is the standard deviation. Values greater than 1.0 indicate a decrease in PCB congener concentration; values less than 1.0 indicate an increase.

(b) $\mathrm{CI}=$ confidence interval.
}

Fractional increases in congeners $\mathrm{Cl}_{5}(105), \mathrm{Cl}_{5}(118), \mathrm{Cl}_{6}(138)$, and $\mathrm{Cl}_{9}(206)$ were also significant for broiled samples $(a=0.05$; see Table 11). Again, inclusion of the $100 \%$ reduction cases for congener $\mathrm{Cl}_{2}(08)$ resulted in a significant $\mathrm{t}$ test indicating a loss of about $65 \%$ of the congener. The modifications for $100 \%$ loss of PCB congeners had little effect on the results as expressed for total PCB because the congeners involyed represented only a small fraction of the total PCB when quantified by the ratio of the 17 congeners used in the study. 
TABLE 10. Students t Test for Testing Significance of Cooking on Specific Congeners in Pan-Fried Fillets of Winter Flounder

\begin{tabular}{|c|c|c|c|c|c|c|c|}
\hline \multirow[t]{2}{*}{ Congener } & \multicolumn{2}{|c|}{ Transformed } & $\begin{array}{l}\% \text { Mean } \\
\text { Change }\end{array}$ & $95 \% \mathrm{CI}^{(\mathrm{b})}$ & $\underline{\mathrm{df}}$ & t Value & Prob. \\
\hline & \multicolumn{7}{|c|}{ Quantifiable concentrations in raw and cooked fillets } \\
\hline $\mathrm{Cl}_{2}(08)$ & 1.04 & $(0.52)$ & 4 & 98 & 10 & 0.23 & 0.8220 \\
\hline $\mathrm{Cl}_{3}(18)$ & 1.23 & $(0.47)$ & 21 & 75 & 20 & 1.22 & 0.2365 \\
\hline $\mathrm{Cl}_{3}(28)$ & 0.95 & $(0.52)$ & -5 & 107 & 20 & -0.46 & 0.6541 \\
\hline $\mathrm{Cl}_{4}(44)$ & 1.12 & $(0.40)$ & 11 & 70 & 20 & 1.35 & 0.1935 \\
\hline $\mathrm{Cl}_{4}(52)$ & 1.01 & $(0.38)$ & 1 & 74 & 20 & 0.09 & 0.9323 \\
\hline $\mathrm{Cl}_{4}(66)$ & 0.88 & $(0.49)$ & -13 & 109 & 20 & -1.14 & 0.2700 \\
\hline $\mathrm{Cl}_{5}(101)$ & 0.94 & $(0.40)$ & -6 & 83 & 20 & -0.68 & 0.5019 \\
\hline $\mathrm{Cl}_{5}(105)$ & 0.78 & $(0.43)$ & -25 & 108 & 20 & -2.41 & 0.0259 \\
\hline $\mathrm{Cl}_{5}(118)$ & 0.79 & $(0.45)$ & -24 & 112 & 20 & -2.19 & 0.0407 \\
\hline $\mathrm{Cl}_{6}(128)$ & 0.95 & $(0.45)$ & -5 & 93 & 19 & -0.52 & 0.6124 \\
\hline $\mathrm{Cl}_{6}(138)$ & 0.82 & $(0.46)$ & -20 & 110 & 20 & -1.82 & 0.0839 \\
\hline $\mathrm{Cl}_{6}(153)$ & 0.88 & $(0.46)$ & -13 & 102 & 20 & -1.23 & 0.2301 \\
\hline $\mathrm{Cl}_{7}(170)$ & 0.89 & $(0.43)$ & -12 & 95 & 20 & -1.23 & 0.2329 \\
\hline $\mathrm{Cl}_{7}(180)$ & 1.02 & $(0.53)$ & 2 & 102 & 20 & 0.14 & 0.8916 \\
\hline $\mathrm{Cl}_{7}(187)$ & 1.04 & $(0.43)$ & 4 & 81 & 20 & 0.39 & 0.6977 \\
\hline $\mathrm{Cl}(195)$ & 0.94 & $(0.53)$ & -6 & 111 & 17 & -0.5 & 0.6215 \\
\hline $\mathrm{Clg}(206)$ & 1.23 & $(0.55)$ & 21 & 88 & 17 & 1.78 & 0.0939 \\
\hline $\mathrm{Cl}_{10}(209)$ & 1.11 & $(0.36)$ & 10 & 64 & 6 & 0.8 & 0.4519 \\
\hline
\end{tabular}

\section{$\mathrm{Cl}_{2}(08)$}

Assumed $100 \%$ reduction when cooked fillet was < detection

$\begin{array}{llllll}1.63 & (0.93) & 49 & 112 & 17 & 2.81\end{array}$

0.0127
(a) Transformation was $e^{\mathrm{F}}$, where $e$ is the base of the ln and $\mathrm{F}$ is the fraction change; (SD) is the standard deviation. Values greater than 1.0 indicate a decrease in PCB congener concentration; values less than 1.0 indicate an increase.
(b) $\mathrm{CI}=$ confidence interval.

The relationship between the transformed data and other aspects of the analysis was examined by regressing transformed total PCB levels against weight change ( $g$ and percentage), initial fillet size before the cooking treatment, and recovery of the internal standard (Table 12). There was no significant relationship except for recovery of the internal standard. This relationship indicated that the higher concentrations of total P.CB were generally associated with the lowest recovery levels of DBOFB. Analysis of variance of the data adjusted for recovery did not indicate any significant difference between treatments, and all subsequent analysis used the reported values. 
TABLE 11. Students $t$ Test for Testing Significance of Cooking on Specific Congeners in Broiled Fillets of Winter Flounder

\begin{tabular}{|c|c|c|c|c|c|c|c|}
\hline Congener & \multicolumn{2}{|c|}{$\begin{array}{l}\text { Transformed } \\
\text { Mean (SD) }\end{array}$} & $\%$ Mean & $95 \% \mathrm{CI}^{(\mathrm{b})}$ & $\underline{\text { df }}$ & $\underline{t \text { Value }}$ & Prob. \\
\hline & \multicolumn{7}{|c|}{ Quantifiable concentrations in raw and cooked fillets } \\
\hline $\mathrm{Cl}_{2}(08)$ & 1.34 & $(0.52)$ & 29 & 76 & 9 & 2.06 & 0.0694 \\
\hline $\mathrm{Cl}_{3}(18)$ & 1.20 & $(0.44)$ & 18 & 72 & 20 & 2.04 & 0.0547 \\
\hline $\mathrm{Cl}_{3}(28)$ & 0.94 & $(0.45)$ & -6 & 94 & 20 & -0.65 & 0.5258 \\
\hline $\mathrm{Cl}_{4}(44)$ & 1.23 & $(0.35)$ & 21 & 56 & 20 & 1.69 & 0.1069 \\
\hline $\mathrm{Cl}_{4}(52)$ & 1.01 & $(0.35)$ & 1 & 68 & 20 & 0.13 & 0.8957 \\
\hline $\mathrm{Cl}_{4}(66)$ & 0.84 & $(0.45)$ & -17 & 105 & 20 & -1.66 & 0.1133 \\
\hline $\mathrm{Cl}_{5}(101)$ & 0.93 & $(0.38)$ & -7 & 80 & 20 & -0.84 & 0.4098 \\
\hline $\mathrm{Cl}_{5}(105)$ & 0.77 & $(0.40)$ & -26 & 102 & 20 & -2.65 & 0.0153 \\
\hline $\mathrm{Cl}_{5}(118)$ & 0.75 & $(0.39)$ & -29 & 102 & 20 & -2.92 & 0.0085 \\
\hline $\mathrm{Cl}_{6}(128)$ & 0.99 & $(0.41)$ & -1 & 81 & 19 & -0.15 & 0.8854 \\
\hline $\mathrm{Cl}_{6}(138)$ & 0.81 & $(0.38)$ & -21 & 92 & 20 & -2.27 & 0.0344 \\
\hline $\mathrm{Cl}_{6}(153)$ & 0.87 & $(0.40)$ & -14 & 90 & 20 & -1.45 & 0.1635 \\
\hline $\mathrm{Cl}$ (170) & 0.83 & $(0.43)$ & -19 & 102 & 20 & -1.85 & 0.0785 \\
\hline $\mathrm{Cl} 7(180)$ & 1.01 & $(0.40)$ & 1 & 78 & 20 & 0.15 & 0.8802 \\
\hline $\mathrm{Cl}$ (187) & 1.03 & $(0.36)$ & 3 & 69 & 20 & 0.39 & 0.7028 \\
\hline $\mathrm{Cl} 8(195)$ & 0.97 & $(0.46)$ & -3 & 93 & 17 & -0.24 & 0.8134 \\
\hline Clg(206) & 1.24 & $(0.48)$ & 22 & 76 & 17 & 2.14 & 0.0471 \\
\hline $\mathrm{Cl}_{10}(209)$ & 0.98 & $(0.65)$ & -2 & 130 & 5 & -0.07 & 0.9499 \\
\hline & & & & & & ctio & \\
\hline $\mathrm{Cl}_{2}(08)$ & & & & & 17 & 2.81 & 0.0127 \\
\hline
\end{tabular}
(a) Transformation was $e^{\mathrm{F}}$, where $e$ is the base of the ln and $\mathrm{F}$ is the fraction change; (SD) is the standard deviation. Values greater than 1.0 indicate a decrease in PCB congener
(b) $\mathrm{CI}=$ confidence interval.

TABLE 12. Regression Analysis of PCB Concentrations (In-transformed and adjusted for recovery) Against Changes in Weight, Precooking Weight, and Recovery of the Internal Standard DBOFB

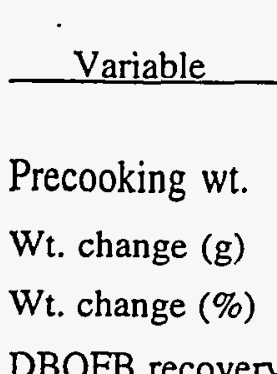

DBOFB recovery

$\frac{\text { ANOVA for Regression }}{\text { Total df } \quad \text { F-test }}$

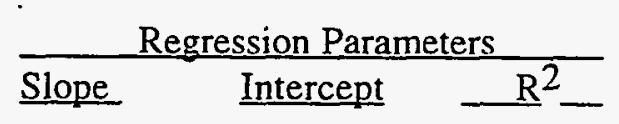

$\begin{array}{lllllll}\text { Precooking wt. } & 62 & 0.167 & 0.684 & -0.01 & 5.56 & 0.003 \\ \text { Wt. change (g) } & 62 & 1.192 & 0.279 & -0.07 & 5.63 & 0.019 \\ \text { Wt. change (\%) } & 62 & 1.782 & 0.187 & -1.89 & 5.74 & 0.028 \\ \text { DBOFB recovery } & 83 & 19.321 & 0.0001 & -5.36 & 9.30 & 0.191\end{array}$




\subsection{DISCUSSION}

This section provides further discussion of the analytical results summarized in Section 3 , including quantification of $\mathrm{PCB}, \mathrm{PCB}$ concentrations in fish from different collection sites, and the effects of cooking on $\mathrm{PCB}$ levels.

\subsection{PCB QUANTIFICATION}

The total PCB quantification method used in this study, in which 17 representative congeners were used for determining total PCB concentrations, is only one of several methods that have been used for determining total $\mathrm{PCB}$ concentrations. Other possible methods of quantification include the following:

1. quantify total PCB by Aroclor or Aroclor mix by using a few congeners that constitute a known response per unit concentration of an Aroclor or Aroclor mix

2. identify and sum the responses of each individual congener by level of chlorination, quantify the levels of chlorination separately using an average response factor for each level of chlorination (determined from analysis of several congeners of each level of chlorination), and then sum the concentrations obtained for the different levels of chlorination to yield total $\mathrm{PCB}$

3. identify and quantify as many of the 209 existing PCB congeners as possible using individual standards and response factors, and then sum these values to yield the total PCB concentration.

The first alternative method is probably the most commonly used for quantifying total PCB. When this method is applied, a few congeners (often as few as two or three) are selected to represent total PCB for quantification. This selection is often done with little consideration given to factors other than chromatographic separation and detector response. The second and third alternative methods are generally more accurate but are less frequently used because they are very time consuming.

The method for total PCB determination that was used in this study is an important improvement to the first alternative method because 1) a relatively large set of representative congeners was used that covers the complete range of chlorination levels; 2) the selected congeners are generally among the most abundant congeners in environmental samples; and 3) these congeners are generally relatively free from chromatographic interference, allowing accurate and reproducible determination. However, the method used in this study may not always be as accurate as the other two alternative methods. The higher level of effort required to quantify using either of those two 
methods was not considered justifiable for this work, because the primary goal of this work was to provide data to determine relative differences in PCB levels between samples. The total PCB determination method used in this study has been used in the Mussel Watch Program and has been found to be reproducible and suitable for accurate quantification of total PCB concentrations in marine sediment and bivalve tissue (Battelle 1991).

\subsection{FISH COLLECTION SITES}

The concentrations of PCBs in fish collected from Restricted Area II of New Bedford Harbor generally were in agreement with data from other studies in which fish have been collected from the three restricted areas of New Bedford Harbor. Restricted Area III is south of Ricketsons and Wilbur Points, and Restricted Area I is inside the New Bedford Harbor hurricane barrier (see Figure 1). These designations indicate areas of fishing closure or restricted fishing and were established by the Massachusetts Department of Public Health as a result of PCB levels measured in seafood from New Bedford Harbor and Buzzards Bay. Area I is closed to the taking of all finfish, shellfish, and lobster. Area II is closed to the taking of bottom-feeding finfish (including winter flounder) and lobster. Area III is closed to the taking of lobster.

Connolly (1991) observed greater variability in PCB concentrations in winter flounder collected from Restricted Area II than from Restricted Areas I or III. The PCB levels measured in this study ranged from 0.014 to $7.00 \mu \mathrm{g} / \mathrm{g}$ wet weight (whole body) and were lower than levels reported in several earlier studies. The highly variable results contributed to the non-significant relationship between fish weight or length, and PCB tissue burden. Kolek and Ceurvels (1981) measured levels exceeding $2 \mu \mathrm{g} / \mathrm{g}$ in the majority of the limited number of winter flounder caught in Restricted Area II for their monitoring between 1976 and 1980. Pruell et al. (1988) measured PCB levels ranging from 0.1 to $7 \mu \mathrm{g} / \mathrm{g}$ in winter flounder collected from Restricted Area I. Rusek (1989) reported PCB levels in edible tissue of striped bass that averaged $22 \mu \mathrm{g} / \mathrm{g}$ and $1.1 \mu \mathrm{g} / \mathrm{g}$ in fish collected from Restricted Areas I and III, respectively, in a large 1988 survey. The available data are too few and scattered over time to draw any firm conclusions regarding trends in PCB levels in fish in New Bedford Harbor.

\subsection{EFFECTS OF COOKING ON PCB LEVELS}

Our results indicated a significant decrease in total PCB levels following deep frying. In contrast, pan frying and broiling resulted in a slight but statistically insignificant increase of around 15 to $17 \%$ in total PCB. A possible explanation for increases in PCBs in the pan-fried treatment 
would be a contribution to the tissue from the butter if it were contaminated with PCBs. It is also possible that the cooking oil could have been contaminated; however, if true, such contamination was not obvious in the results. This proposition is unlikely and is weakened by the fact that the broiled treatment did not use butter or oil, yet still showed a statıstically insignificant net increase in PCB levels. The data analysis was hampered by high variability in the absolute levels of PCBs found in the tissue. Higher concentrations of PCBs also tended to be located in the posterior section (Section III), even though AṆOVA for effects due to section were not significant (see Table 6). The differences between top and bottom fillets also were not significant.

Results of the analysis of individual congeners paralleled the results for total PCB. Congener $\mathrm{Cl}_{2}(08)$ was particularly sensitive to reduction by cooking, while congeners $\mathrm{Cl}_{5}(105), \mathrm{Cl}_{5}(118)$, and $\mathrm{Cl}_{6}$ (138) individually showed significant increases following cooking by either pan frying or broiling; increases in PCBs based on estimated total PCB was not significant. Moreover, congener $\mathrm{Cl}_{2}(08)$ has the lowest molecular weight, and is the most volatile and most polar of the congeners included in this study. The assumption that a less-than-detection value in the cooked fillet indicated complete removal of that congener introduces a slight bias for overestimating loss of PCBs during cooking. Moreover, in some cases, quantifiable amounts of specific congeners were reported in cooked fillets where levels were less than detection in the raw fillet. In these cases, the data were not used to estimate fractional change for statistical analyses because the value was undefined (denominator of fractional change was 0 ) and the congener level in the cooked sample was generally close to the detection limit.

Others also have reported increases in PCB levels following cooking (Table 13). This conclusion is understandable when results are reported on a gravimetric basis without adjusting for loss of water and fat during cooking. Increases in PCBs as high as $36 \%$ have been reported in carp when calculated using a mass-balance approach that accounts for weight loss in the fillet (Zabik et al. 1982). Initially, they reported that extractability of PCBs is lower in raw tissue than in cooked tissue and recommended four solvent extractions on raw fish to obtain maximum PCB yields. For our analyses, three extractions were used, with the third extraction lasting for $30 \mathrm{~min}$ on a shaker. We believe these three extractions adequately removed the majority of the available PCBs.

Zabik et al. (1982) also suggested that extractability of PCBs was related to a high percentage of lipid in the tissue. Their early work with lake trout indicated significant reductions in total PCBs due to cooking when expressed on a mass basis. The lake trout had a high amount of lipid (25 to $30 \%$ ) in the fillets. In contrast, carp used in their 1982 study had $7.7 \pm 3.2 \%$ lipid. The winter flounder used in this study had lipid levels ranging from 0.8 to $4.5 \%$ (mean $=1.8 \%$ ). While increased lipid content in fish flesh may be associated with greater PCB losses during cooking, there 
TABLE 13. Estimates of Cooking Effects on PCB Levels in Fish (wet-weight basis)

\begin{tabular}{|c|c|}
\hline Species & Cooking Treatment \\
\hline Bluefish & Baked, 1 h at $325^{\circ} \mathrm{F}$ \\
\hline Bluefish & $\begin{array}{l}\text { Baked to } 80^{\circ} \mathrm{C} \text { it (a) } \\
\text { Broiled to } 75-90^{\circ} \mathrm{C} \text { it } \\
\text { Pan fried to } 80^{\circ} \mathrm{C} \text { it } \\
\text { Poached to } 80-90^{\circ} \mathrm{C} \text { it }\end{array}$ \\
\hline White croaker & Pan fried $8 \mathrm{~min}$ at $190^{\circ} \mathrm{C}$ \\
\hline Lake trout & $\begin{array}{l}\text { Roasted to } 75^{\circ} \mathrm{C} \text { it } \\
\text { Roasted to } 75^{\circ} \mathrm{C} \text { it } \\
\text { Roasted to } 75^{\circ} \mathrm{C} \text { it } \\
\text { Broiled to } 75^{\circ} \mathrm{C} \text { it } \\
\text { Microwaved to } 75^{\circ} \mathrm{C} \text { it }\end{array}$ \\
\hline Lake trout & $\begin{array}{l}\text { Irradiated (gamma, } 1000 \mathrm{krad} \text { ) } \\
\text { Irrad. \& broiled to } 75^{\circ} \mathrm{C} \text { it }\end{array}$ \\
\hline Chinook salmon & $\begin{array}{l}\text { Baked to } 75^{\circ} \mathrm{C} \text { it } \\
\text { Baked in bag to } 75^{\circ} \mathrm{C} \text { it } \\
\text { Poached to } 75^{\circ} \mathrm{C} \text { it } \\
\text { Baked to } 75^{\circ} \mathrm{C} \text { it } \\
\text { Baked in bag to } 75^{\circ} \mathrm{C} \text { it } \\
\text { Poached to } 75^{\circ} \mathrm{C} \text { it }\end{array}$ \\
\hline Coho salmon & $\begin{array}{l}\text { Baked to } 75^{\circ} \mathrm{C} \text { it } \\
\text { Baked in bag to } 75^{\circ} \mathrm{C} \text { it } \\
\text { Poached to } 75^{\circ} \mathrm{C} \text { it } \\
\text { Baked to } 75^{\circ} \mathrm{C} \text { it } \\
\text { Baked in bag to } 75^{\circ} \mathrm{C} \text { it } \\
\text { Poached to } 75^{\circ} \mathrm{C} \text { it }\end{array}$ \\
\hline Carp & $\begin{array}{l}\text { Deep fried to } 75^{\circ} \mathrm{C} \text { it } \\
\text { Poached to } 75^{\circ} \mathrm{C} \text { it } \\
\text { Charbroiled to } 75^{\circ} \mathrm{C} \text { it } \\
\text { Microwaved to } 76^{\circ} \mathrm{C} \text { it } \\
\text { Roasted to } 75^{\circ} \mathrm{C} \text { it }\end{array}$ \\
\hline
\end{tabular}

\begin{tabular}{l} 
Change \\
\hline$+8 \%$ on ppm basis \\
$-7.5 \%$ \\
$-7.5 \%$ \\
$-7.5 \%$ \\
$-7.5 \%$ \\
$-65 \%$ mass balance \\
$-28 \%$ mass balance \\
$-34 \%$ mass balance \\
$-40 \%$ mass balance \\
$-50 \%$ mass balance \\
$-53 \%$ mass balance \\
$-26 \%$ mass balance \\
$-38 \%$ mass balance \\
$-43 \%$ mass balance \\
$-15.2 \%$ fat basis \\
$-24.2 \%$ fat basis \\
$+1.3 \%$ fat basis \\
$+0.5 \%$ fat basis \\
$-18.1 \%$ fat basis \\
$-1.8 \%$ fat basis \\
$-3.5 \%$ fat basis \\
$-6.1 \%$ fat basis \\
$+8.7 \%$ fat basis \\
$+9.8 \%$ fat basis \\
$+6.7 \%$ fat basis \\
$+13.6 \%$ fat basis \\
$+36 \%$ mass balance \\
$+13 \%$ mass balance \\
$+33 \%$ mass balance \\
$+8.3 \%$ mass balance \\
\end{tabular}

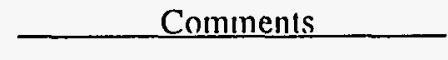

Average for all four

cooking methods

Santa Monica Bay

Orange County, Ca

With skin

Without skin

Combined cooking treatments

Arochlor 1248 , fat trimmed Arochlor 1248, fat trimmed

Arochlor 1248, fat trimmed

Arochlor 1254 , fat trimmed

Arochlor 1254, fat trimmed

Arochlor 1254 , fat trimmed

Arochlor 1248, fat trimmed

Arochlor 1248, fat trimmed

Arochlor 1248, fat trimmed

Arochlor 1254, fat trimmed

Arochlor 1254, fat trimmed

Arochlor 1254, fat trimmed
Reference

Trotter et al. 1989

Armbruster et al.

1989

Puffer and Gossett 1983

Zabik et al. 1979

Cichy et al. 1979

Smith et al. 197.3

Smith et al. 1973

Zabik et al. 1982 
are also contrary data. Trotter et al. (1989) reported increases in PCB levels in bluefish (11.8\% lipid) following cooking; and decreases in PCB levels following cooking have been reported in salmon, where precooking lipid levels ranged from 2.65 to $3.59 \%$ (Smith et al. 1973). Moreover, most weight loss following cooking is due to losses in moisture, either by vaporization or in drippings: there generally is not a significant change in lipid levels on a gravimetric basis following cooking. Deep frying, however, increases the measurable amount of lipid in cooked tissue by absorption of the cooking oil (Zabik et al. 1982).

A direct comparison of our results with others is difficult because of differences in sample processing, cooking methods, and PCB analysis. The factors that contribute to decreases or increases in PCB levels in cooked fillets are complex. It is possible that the cooking oil or butter used for pan frying could have contributed PCBs if it were contaminated, but this proposition is unlikely. Our study, which required that a fillet be sectioned into three subsamples, was designed to prevent any bias from position of the fillets. Our analysis by section was close to showing that section was a significant variable relative to $\mathrm{PCB}$ levels. We were not able to demonstrate a relationship between lipid content in the three fillet sections and PCB levels. Other variables include total surface area of the fillet. thickness of the fillet, and interactions of these variables with the cooking methods. Pan-fried fillets have less surface area exposed to air, which might reduce volatilization of PCBs compared with broiled fillets. The deep frying process creates unique cooking conditions that accelerate drying of the fillet compared with broiling and pan frying.

Our data, considered with other published data on the effects of cooking on PCB levels in fish flesh, indicate that the influence of broiling and pan frying on PCB levels in winter flounder fillet is insignificant. Our data indicate that PCB concentrations measured in raw tissue would be suitable for risk assessment of fish consumption when fillets are pan fried or broiled under conditions similar to those used in this study. Deep frying appears to significantly reduce PCB levels. This conclusion is logical because the cooking oil itself could be considered an extraction solvent. However, it should be emphasized that the range in PCB concentrations encountered in winter flounder fillets was very large and a large degree of variability and resulting statistical error was associated with our estimates. 


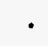

- 


\subsection{REFERENCES}

Abacus Concepts. 1986. Statview 512t. Brainpower. Inc., Calabasas, California.

Alford-Stevens, A. L., T. A. Bellar, J. W. Eichelberger, and W. L. Budde. 1986. "Characterization of Commercial Aroclors by Automated Mass Spectrometric Determination of Polychlorinated Biphenyls by Level of Chlorination." Anal. Chem. 58:2014-2022.

Armbruster, G., K. L. Gall, W. H. Gutenmann, and D. J. Lisk. 1989. "Effects of Trimming and Cooking on Polychlorinated Biphenyls (PCB) Residues in Bluefish." J. Food Safety 9:235-244.

Battelle Ocean Sciences (Battelle). 1990. Phase 1 Period 2 Work/ Quality Assurance Project Plan for Collection of Bivalve Molluscs and Surficial Sediments, and Performance of Analyses for Organic Chemicals and Toxic Trace Metals. Prepared for the Department of Commerce. National Oceanic and Atmospheric Administration, Ocean Assessment Division, Rockville, Maryland.

Battelle Ocean Sciences (Battelle). 1991. Collection of Bivalves and Surficial Sediments from Coastal U.S. Atlantic and Pacific Locations and Analyses for Organic Chemicals and Trace Elements. Prepared for the Department of Commerce, National Oceanic and Atmospheric Administration, Ocean Assessment Division, Rockville, Maryland.

Cichy, R. F., M. E. Zabik, and C. M. Weaver. 1979. "Polychlorinated Biphenyl Reduction in Lake Trout by Irradiation and Cooking." Bull. Environ. Contam. Toxicol. 22:807-812.

Connolly, J. P. 1991. "Application of a Food Chain Model to Polychlorinated Biphenyl Contamination of the Lobster and Winter Flounder Food Chains in New Bedford Harbor." Environ. Sci. Technol. 25:760-770.

Cordle, F., R. Locke, and J. Springer. 1982. "Risk Assessment in a Federal Regulatory Agency: An Assessment of Risk Associated with the Human Consumption of Some Species of Fish Contaminated with Polychlorinated Biphenyls (PCBs)." Environmental Health Perspect. 45:171-182.

Courtney, W.A.M., and G.R.W. Denton. 1976. "Persistence of Polychlorinated Biphenyls in the Hard-Clam (Mercenaria mercenaria) and the Effect upon the Distribution of These Pollutants in the Estuarine Environment." Environ. Pollut. 10:55-64.

Eisenberg, M., R. Mallman, and H. S. Tubiash. 1980. "Polychlorinated Biphenyls in Fish and Shellfish of the Chesapeake Bay." Marine Fisheries Review, February 1980, pp. 21-25.

Kolek, A., and R. Ceurvels. 1981. Polychlorinated Biphenyl (PCB) Analyses of Marine Organisms in the New Bedford Area. 1976-1980. Massachusetts Division of Marine Fisheries Publ. \#12851-36125-6-82-CR, Boston, Massachusetts.

Pruell, R. J., R. D. Bowen, S. J. Fluck, J. A. LiVolsi, D. J. Cobb, and J. L. Lake. 1988. PCB Congeners in American Lobster. Homarus americanus, and Winter Flounder. Pseudopleuronectes americanus, from New Bedford Harbor, Massachusetts. EPA Rep. \#6001X-891331, final report prepared for the.U.S. Environmental Protection Agency, Exposure Assessment Group, Washington, D.C.

Puffer, H. W., and R. W. Gossett. 1983. "PCB, DDT, and Benzo(a)pyrene in Raw and Pan-Fried White Croaker (Genyonemus lineatus)." Bull. Environ. Contam. Toxicol. 30:65-73. 
Rusek, T. F. 1989. Polychlorinated Biphenyls (PCB's) in Striped Bass, Morone saxatilis, of Buzzards Bay and the Acushnet River. Master's thesis, Southeastern Massachusetts University, North Dartmouth, Massachusetts.

Skea, J. C., H. A. Simonin, E. J. Harris, S. Jacking, J. J. Spangnoli, J. Symula, and J. R. Colquhoun. 1979. "Reducing Levels of Mirex, Arochlor 1254, and DDE by Trimming and Cooking Lake Ontario Brown Trout (Salmo Tritta Linnaeus) and Smallmouth Bass (Micropterus dolomieui Lecepede')." J. Great Lakes Res. 5:153-159.

Smith, W. E., K. Funk, and M. E. Zabik. 1973. "Effects of Cooking on Concentrations of PCB and DDT Compounds in Chinook (Oncorhynchus tshawytscha) and Coho (ㅇ. kisutch) Salmon from Lake Michigan.". J. Fish. Res. Bd. Canada 30:702-706.

Trotter, W. J., P..E. Corneliussen, R. R. Laski, and J. J. Vannelli. 1989. "Levels of Polychlorinated Biphenyls in Bluefish Before and After Cooking." J. Assoc. Off. Anal. Chem. 72:501-503.

Zabik, M. E., P. Hoojjat, and C. M. Weaver. 1979. "Polychlorinated Biphenyls, Dieldrin and DDT in Lake Trout Cooked by Broiling, Roasting or Microwave." Bull. Environ. Contam. Toxicol. 21:136143.

Zabik, M. E., C. Merrill; and M. J. Zabik. 1982. "PCBs and Other Xenobiotics in Raw and Cooked Carp." Bull. Environ. Contam. Toxicol. 28:710-715. 
APPENDIX A

PCB ANALYSIS OF FILLET TISSUE 
TABLE A.1. PCB Congener Concentrations in a 1:1 Mix of Aroclor 1242 and Aroclor 1254, and the Ratio of Congener Concentration to Total PCB

Battelle Ocean Sciences file: AROCLOR

Val idated:

Created: BK 03/11/91

Sample ID

C.2(08)

CL3(18)

CL3(28)

$\because-4(52)$

Cl4(44)

CL4(66)

CL5(101)

CL.5(118)

CL6(153)

CL5(105).

CL6(138)

CL7(187)

CL6(128)

CL7(180)

CL7(170)

CL8(195)

CL9(206)

CL10(209)

Sum of 18 Congeners

Total PCB Added

Sum of 18/Total PCB Added

Sum of 17 Congeners

rotal PCB Added

Sum of 17/Total PCB Added 1242/1254 1242/1254

$$
1242 / 1254
$$

$\begin{array}{rr}102.46 & 101.50 \\ 97.90 & 102.27 \\ 110.10 & 109.52 \\ 98.66 & 101.42 \\ 72.21 & 74.62 \\ 147.48 & 153.92 \\ 99.53 & 107.80 \\ 98.25 & 105.16 \\ 60.21 & 66.29 \\ 87.00 & 92.30 \\ 87.08 & 96.69 \\ 8.54 & 9.62 \\ 28.06 & 28.92 \\ 16.74 & 17.33 \\ 12.82 & 15.48 \\ 0.98 & 0.95 \\ 0.45 & 0.35 \\ \text { ND } & \text { ND }\end{array}$

1128.46

2000.000

0.564

2000.000

1115.64

2000.00

0.558
1152.92

2000.00

0.576
AROCLOR I AROCLOR II AROCLOR III
1184.14

0.592

99.05

101.18

108.19

102.06

72.80

152.38

109.15

103.43

66.82

89.44

95.81

7.71

27.54

16.23

11.73

0.72

0.42

HD

1164.64

2000.00

0.582

1168.66

2000.00

0.584
PCB Concentration Changes in Cooked Seafood Phase 1: Winter Flounder

Project Number: G1969-0003

Data reported in $\mathrm{ng}$.

$\begin{array}{rrr}\text { AVERAGE } & \text { STD } & \text { XRSD } \\ \text { AROCLOR } & \text { DEV } & \\ & & \\ 101.00 & 1.43 & 1.4 \\ 100.45 & 1.86 & 1.8 \\ 109.27 & 0.80 & 0.7 \\ 100.71 & 1.48 & 1.5 \\ 73.21 & 1.03 & 1.4 \\ 151.26 & 2.74 & 1.8 \\ 105.50 & 4.25 & 4.0 \\ 102.28 & 2.94 & 2.9 \\ 64.44 & 3.00 & 4.7 \\ 89.58 & 2.16 & 2.4 \\ 93.19 & 4.34 & 4.7 \\ 8.62 & 0.79 & 9.1 \\ 28.17 & 0.57 & 2.0 \\ 16.77 & 0.45 & 2.7 \\ 13.34 & 1.58 & 11.8 \\ 0.89 & 0.12 & 13.1 \\ 10.41 & 0.04 & 9.9 \\ \text { HA } & \text { HA } & \text { HA } \\ & & \\ & & \\ 1159.08 & 23.07 & 2.0 \\ \text { HA } & \text { HA } & \text { HA } \\ 0.580 & 0.01 & 2.0 \\ & & \\ 1145.74 & 22.23 & 1.9 \\ \text { HA } & \text { HA } & \text { HA } \\ 0.573 & 0.01 & 1.9 \\ & & \end{array}$


TABLE A.2. PCB Concentrations in the Untreated Samples

Battelle oceon Sciences

file: PCB_UN

Vol idated:

Created: GSD 06/11/91

Edited:

PCB Concentrotion changes in cooked Seafood

Phose 1: Winter flounder

Project Number: 61969-0005

Data reported in $\mathrm{ng} / \mathrm{g}$ wet weight (procedural blank reparted in total $\mathrm{ng}$ ).

\begin{tabular}{|c|c|c|c|c|c|c|c|c|c|c|c|c|c|}
\hline Sample ID & JG24PB & JL 16PB & $\begin{array}{r}\text { MFO1-T } \\
\text {-UH }\end{array}$ & $\begin{array}{r}\text { WFO2-B } \\
-U H\end{array}$ & $\begin{array}{r}\text { UF03-T } \\
\text {-UN }\end{array}$ & $\begin{array}{r}\mathrm{MFO4- \theta} \\
-U \mathrm{~N}\end{array}$ & $\begin{array}{r}\text { MF05-T } \\
\text {-UN }\end{array}$ & $\begin{array}{r}\text { MFO6-B } \\
\text {-UN }\end{array}$ & $\begin{array}{r}\text { HFO7-T } \\
\text {-UN }\end{array}$ & $\begin{array}{r}\text { MFOB-B } \\
\text {-UN }\end{array}$ & $\begin{array}{r}\text { WF09.T } \\
\text {-UN }\end{array}$ & $\begin{array}{r}\text { HF 10-B } \\
\text {-UN }\end{array}$ & $\begin{array}{r}\text { UF11-T } \\
\text {-UH }\end{array}$ \\
\hline$C L 2(08)$ & ND & HD & 0.49 & 1.07 & 0.92 & HD & ND & 0.38 & 0.65 & ND & 0.79 & 1.01 & 0.98 \\
\hline $\cos 3(18)$ & HD & ND & 0.23 & 2.86 & 3.71 & 0.77 & 7.84 & 0.34 & 0.15 & 7.37 & 1.99 & 4.13 & 1.08 \\
\hline $\operatorname{CL} 3(28)$ & ND & ND & 0.40 & 17.50 & 33.04 & 7.48 & 160.61 & 2.69 & 0.33 & 47.52 & 2.80 & 23.60 & 1.90 \\
\hline$C(4(52)$ & ND & ND & 0.48 & 7.68 & 12.43 & 2.09 & 11.92 & 1.78 & 0.50 & 32.16 & 3.90 & 8.13 & 1.58 \\
\hline $\operatorname{CL4}(44)$ & ND & HD & 0.25 & 2.38 & 1.60 & 0.67 & 2.17 & 0.38 & 0.18 & 2.94 & 1.23 & 1.51 & 0.86 \\
\hline$C L 4(66)$ & ND & ND & 0.30 & 58.39 & 45.69 & 21.62 & 272.37 & 6.73 & 1.33 & 53.17 & 8. 75 & 32.91 & 2.02 \\
\hline $\operatorname{cls}(101)$ & ND & 40 & 0.65 & 21.21 & 23.09 & 16.06 & 44.92 & 8.40 & 1.42 & 33.70 & 6.62 & 9.06 & 1.37 \\
\hline $\operatorname{cLs}(118)$ & ND & No & 0.95 & 258.64 & 116.80 & 54.37 & 605.07 & 17.45 & 2.19 & 112.28 & 28.94 & 47.16 & 2.69 \\
\hline CL6(153) & ND & ND & 1.69 & 365.99 & 135.55 & 60.78 & 541.81 & 20.17 & 4.03 & 134.58 & 37.77 & 49.18 & 3.46 \\
\hline $\operatorname{CLS}(105)$ & HD & ND & 0.16 & 51.52 & 21.77 & 11.03 & 103.91 & 2.77 & 0.79 & 26.36 & 5.47 & 19.50 & 0.85 \\
\hline$C L 6(138)$ & NO & ND & 1.48 & 286.02 & 98.08 & 52.57 & 393.19 & 18.74 & 3.28 & 107.40 & 27.64 & 41.13 & 2.91 \\
\hline $\operatorname{cL} 7(187)$ & HD & ND & 0.37 & 6.34 & 4.61 & 4.65 & 20.05 & 1.96 & 1.39 & 7.97 & 2.18 & 4.58 & 0.79 \\
\hline$C L 6(128)$ & ND & ND & ND & 67.53 & 17.97 & 10.22 & 33.49 & 1.78 & 0.66 & 12.14 & 5.62 & 9.92 & 0.61 \\
\hline$C L 7(180)$ & ND & ND & 0.48 & 72.28 & 21.26 & 9.56 & 72.05 & 2.42 & 1.95 & 17.38 & 5.33 & 10.26 & 1.28 \\
\hline$c L 7(170)$ & ND & ND & 0.15 & 42.48 & 12.99 & 6.46 & 42.37 & 1.77 & 0.77 & 12.40 & 3.34 & 8.33 & 0.27 \\
\hline CLB(195) & ND & ND & NO & 3.82 & 1.02 & 0.88 & 2.69 & 0.23 & 0.49 & 0.74 & 0.67 & 1.07 & 0.16 \\
\hline$C L 9(206)$ & NO & No & ND & 3.69 & 1.14 & 0.94 & 2.74 & 0.26 & 0.59 & 1.08 & 0.95 & 0.86 & 0.24 \\
\hline CL10(209) & NO & ND & ND & 1.07 & ND & MD & ND & MD & 0.47 & ND & 0.53 & 0.34 & 0.18 \\
\hline Sum of 18 Congeners & ma & Ha & 8.07 & 1270.47 & 551.66 & 260.13 & 2317.19 & 88.26 & 21.15 & 609.19 & 144.52 & 272.68 & 23.21 \\
\hline Total PCB & MA & Mn & 13.91 & 2190.47 & 951.13 & 448.51 & 3995.16 & 152.16 & 36.47 & 1050.33 & 249.17 & 470.13 & 40.02 \\
\hline Sum of 17 Congeners & MA & ma & 7.92 & 1227.99 & 538.67 & 253.67 & 2274.83 & 86.48 & 20.38 & 596.79 & 141.17 & 264.34 & 22.94 \\
\hline Total PCB & MA & HA & 13.83 & 2143.09 & 940.09 & 442.71 & 3970.03 & 150.93 & 35.57 & 1041.52 & 246.37 & 461.33 & 40.03 \\
\hline
\end{tabular}

The procedural blank JG24PB was processed with uPDT, 10, 11, 14, and 21. JL16PB was processed with the rest of the samples.

The sum of the 17 is the sum of all listed PCB congeners excluding $\mathrm{CL} 7(170)$. 
TABLE A.2. (contd)

Bottelle Ocean Sciences

file: PCB_UM

Val idated:

\begin{tabular}{|c|c|c|c|c|c|c|c|c|c|c|}
\hline Semple 10 & $\begin{array}{r}\text { MF 12-8 } \\
-U N\end{array}$ & $\begin{array}{r}\text { WF 13-T } \\
- \text { UH }\end{array}$ & $\begin{array}{r}\text { MF } 14-8 \\
-U N\end{array}$ & $\begin{array}{r}\text { UF 15-I } \\
\text {-UN }\end{array}$ & $\begin{array}{r}\text { WF 16-8 } \\
- \text { UN }\end{array}$ & $\begin{array}{r}\text { WF 17-1 } \\
-U H\end{array}$ & $\begin{array}{r}\text { WF 18-B } \\
-U N\end{array}$ & $\begin{array}{r}\text { MF 19-T } \\
\text {-UW }\end{array}$ & $\begin{array}{r}\text { MF 20-B } \\
-U \mathrm{H}\end{array}$ & $\begin{array}{r}\text { MF } 21-T \\
-U N\end{array}$ \\
\hline $\mathrm{CL} 2(0 B)$ & 5.80 & 0.44 & 0.96 & 0.48 & 0.52 & 0.35 & NO & 0.32 & 0.68 & 1.13 \\
\hline $\operatorname{CL3}(18)$ & 13.75 & 0.52 & 0.82 & 0.31 & 0.90 & 0.45 & 0.66 & 0.14 & 1.72 & 1.41 \\
\hline$C L 3(28)$ & 122.44 & 1.73 & 0.82 & 0.35 & 0.99 & 5.86 & 10.28 & 1.58 & 5.82 & 4.34 \\
\hline$C L 4(52)$ & 24.62 & 2.35 & 1.34 & 0.32 & 1.12 & 4.63 & 2.54 & 0.22 & 5.15 & 3.88 \\
\hline$C 14(44)$ & 5.32 & 0.62 & 0.72 & 0.18 & 0.49 & 0.61 & 0.70 & 0.15 & 1.35 & 1.10 \\
\hline$C L 4(86)$ & 164.09 & 3.60 & 1.89 & 0.71 & 1.74 & 2.15 & 24.73 & 4.77 & 15.40 & 13.10 \\
\hline $\operatorname{cLS}(101)$ & 64.47 & 5.89 & 1.35 & 1.18 & 1.72 & $29.0 \mathrm{~B}$ & 11.91 & 1.23 & 21.22 & 9.60 \\
\hline CLS(118) & 259.64 & 13.94 & 2.43 & 2.76 & 6.16 & 68.03 & 130.00 & 19.28 & 76.45 & 25.75 \\
\hline CL6(153) & 216.25 & 22.20 & 3.47 & 4.47 & 10.70 & 78.57 & 161.52 & 23.34 & 92.23 & 28.74 \\
\hline $\operatorname{CL} 5(105)$ & 69.92 & 2.76 & 0.80 & 0.48 & 0.99 & 6.69 & 19.03 & 3.22 & 10.24 & 9.76 \\
\hline$C L 6(13 B)$ & 181.76 & 19.27 & 3.01 & 3.55 & 8.06 & 68.03 & 101.25 & 20.77 & 71.40 & 27.40 \\
\hline $\operatorname{cL} 7(187)$ & 10.28 & 2.75 & 0.90 & 0.75 & 0.83 & 5.66 & 4.56 & 1.98 & 5.93 & 3.61 \\
\hline$C(6(12 B)$ & 37.62 & 2.50 & 0.72 & 0.32 & 0.65 & 4.80 & 7.45 & 2.13 & 3.82 & 5.11 \\
\hline $\operatorname{cL} 7(180)$ & 25.98 & 3.55 & 1.39 & 0.74 & 1.61 & 9.94 & 17.52 & 3.49 & 12.25 & 7.05 \\
\hline CL.7(170) & 16.94 & 2.64 & 0.42 & 0.22 & 0.98 & 6.60 & 11.86 & 2.35 & 8.11 & 5.29 \\
\hline CL8(195) & 0.89 & 0.28 & 0.22 & No & NO & 0.30 & 0.43 & 0.21 & 0.50 & 0.80 \\
\hline$C L 9(206)$ & 1.18 & 0.46 & 0.34 & ND & KD & 0.35 & 0.81 & 0.28 & 0.55 & 0.60 \\
\hline CL10(209) & NO & NO & 0.25 & HD & NO & HD & ND & NO & ND & 0.33 \\
\hline Sum of 18 Congeners & 1220.94 & 85.49 & 21.83 & 16.80 & 37.45 & 292.28 & 485.24 & 85.47 & 332.79 & 149.00 \\
\hline Total PCB & 2105.07 & 147.40 & 37.64 & 28.97 & 64.57 & 503.93 & 836.61 & 147.36 & 573.78 & 256.89 \\
\hline Sum of 17 Congeners & 1204.00 & 82.85 & 21.41 & 16.59 & 36.47 & 285.48 & 473.38 & 83.11 & 324.69 & 143.71 \\
\hline Total PCB & 2101.23 & 144.60 & 37.36 & 28.95 & 63.65 & 498.23 & B26.14 & 145.05 & 566.64 & 250.80 \\
\hline
\end{tabular}

PCB Concentration Changes in cooked Seafood

Phase 1: Hinter Flounder

Project Number: 61969-0005

Date reported in ng/g wet weight (procedural blank reported in total ng). 
TABLE A.3. PCB Concentrations in the Deep-Fried Samples

Battelle Ocean Sciences

File: PCB_DF

Val idated:

Created: GSD 06/11/91

Edited:

\begin{tabular}{|c|c|c|c|c|c|c|c|c|c|c|c|c|c|}
\hline Serple 10 & JG24PB & JITSPB & $\begin{array}{r}\text { WFO1-B- } \\
\text { I-DF }\end{array}$ & $\begin{array}{r}\text { II-OF } \\
\text { MF05-T- }\end{array}$ & $\begin{array}{c}\text { WF03-B- } \\
\text { III-DF }\end{array}$ & $\begin{array}{r}\text { WF04-I- } \\
\text { I-DF }\end{array}$ & $\begin{array}{r}\text { WF05-B- } \\
11 \text {-DF }\end{array}$ & $\begin{array}{l}\text { MF06-T- } \\
\text { III-OF }\end{array}$ & $\begin{array}{r}\text { HFO7-B- } \\
1-D F\end{array}$ & $\begin{array}{r}\text { WF08-T- } \\
\text { II-DF }\end{array}$ & $\begin{array}{l}\text { WFO9-B } \\
\text { III-DF }\end{array}$ & $\begin{array}{r}\text { WF 10-7- } \\
\text { 1-DF }\end{array}$ & $\begin{array}{r}\text { WF 11-B- } \\
\quad 11-D F\end{array}$ \\
\hline CL2(08) & No & ND & No & HD & 0.44 & HD & ND & ND & 0.12 & ND & 0.25 & 0.90 & 0.36 \\
\hline $\mathrm{Cl} 3(18)$ & HD & ND & 0.27 & 2.51 & 2.83 & 0.29 & 6.33 & 0.19 & 0.07 & 9.20 & 1.04 & 4.55 & 0.61 \\
\hline CL3(28) & HO & MD & 0.20 & 17.94 & 34.47 & 2.68 & 176.38 & 1.39 & 0.43 & 76.33 & 2.77 & 26.80 & 0.68 \\
\hline $\operatorname{cl4}(52)$ & ND & ND & 0.30 & 8.26 & 11.64 & 0.60 & 9.96 & 0.88 & 0.30 & 46.23 & 2.90 & 8.51 & 1.02 \\
\hline$C L 4(44)$ & HD & 0.95 & 0.33 & 2.35 & 1.47 & 0.29 & 1.22 & 0.30 & 0.11 & 3.05 & 1.17 & 1.61 & 0.42 \\
\hline$C 16(66)$ & HD & ND & 0.24 & 72.80 & 52.51 & 5.45 & 360.91 & 2.93 & 0.87 & 86.89 & 6.18 & 35.42 & 1.14 \\
\hline $\operatorname{CLS}(101)$ & ND & ND & 0.43 & 22.31 & 25.11 & 4.04 & 36.49 & 3.80 & 1.02 & 46.95 & 4.64 & 8.09 & 0.82 \\
\hline $\operatorname{CLS}(118)$ & No & ND & 0.75 & 405.48 & 158.80 & 12.64 & 769.88 & 6.79 & 1.76 & 199.68 & 22.49 & 50.02 & 1.62 \\
\hline$C L 6(153)$ & ND & ND & 1.32 & 526.54 & 154.28 & 11.15 & 586.33 & 6.47 & 3.09 & 232.43 & 25.06 & 54.24 & 2.61 \\
\hline CLS(105) & ND & ND & 0.16 & 72.07 & 40.55 & 2.71 & 105.63 & 1.18 & 0.48 & 45.51 & 5.04 & 21.84 & 0.47 \\
\hline$C L 6(138)$ & HD & ND & 0.87 & 437.00 & 129.89 & 10.13 & 426.59 & 5.97 & 2.55 & 189.22 & 20.91 & 46.84 & 2.02 \\
\hline $\operatorname{cL}(187)$ & ND & ND & 0.27 & 6.19 & 5.05 & 0.61 & 13.78 & 0.42 & 1.01 & 8.81 & 1.14 & 4.85 & 0.44 \\
\hline$C L 6(128)$ & ND & ND & 0.05 & 79.50 & 24.60 & 1.51 & 23.17 & 0.26 & 0.38 & 12.38 & 2.75 & 9.93 & 0.29 \\
\hline $\operatorname{cL}(180)$ & HD & ND & 0.21 & 72.84 & 24.58 & 1.24 & 48.77 & 0.46 & 1.44 & 23.15 & 3.09 & 11.57 & 0.81 \\
\hline $\operatorname{cl} 7(170)$ & NO & 3.45 & 0.39 & 39.23 & 15.23 & 0.79 & 26.93 & 0.39 & 0.45 & 14.65 & 2.61 & 9.49 & 0.17 \\
\hline CL8(195) & NO & ND & 0.03 & 3.27 & 0.89 & 0.08 & 1.92 & MD & 0.35 & 0.96 & 0.22 & 1.25 & 0.09 \\
\hline$C L 9(206)$ & ND & ND & 0.01 & 1.91 & 0.59 & 0.06 & ND & ND & 0.47 & 0.95 & 0.17 & 1.00 & 0.11 \\
\hline$C L 10(209)$ & NO & ND & 0.08 & ND & 0.13 & 0.04 & ND & ND & 0.39 & ND & 0.15 & 0.31 & 0.21 \\
\hline Sum of 18 Congeners & ma & ma & 5.90 & 1770.19 & 683.15 & 54.31 & 2614.30 & 31.40 & 15.27 & 996.38 & 102.50 & 297.14 & 13.88 \\
\hline Total PCB & MA & MA & 10.17 & 3052.04 & 1177.85 & 93.64 & 4507.42 & 54.14 & 26.33 & 1717.89 & 176.73 & 512.30 & 23.93 \\
\hline Sum of 17 Congeners & MA & ma & 5.51 & 1730.96 & 667.93 & 53.52 & 2587.37 & 31.01 & 14.82 & 981.73 & 99.89 & 287.73 & $13.7 t$ \\
\hline Totel PCB & MA & HA & 9.61 & 3020.87 & 1165.67 & 93.40 & 4515.47 & 54.12 & 25.86 & 1713.31 & 174.33 & 502.15 & 23.92 \\
\hline
\end{tabular}

\begin{tabular}{|c|c|c|c|c|c|c|c|c|c|c|c|c|c|}
\hline Serple 10 & JG24PB & JITSPB & $\begin{array}{r}\text { WFO1-B- } \\
\text { I-DF }\end{array}$ & $\begin{array}{r}\text { II-OF } \\
\text { MF05-T- }\end{array}$ & $\begin{array}{c}\text { WF03-B- } \\
\text { III-DF }\end{array}$ & $\begin{array}{r}\text { WF04-I- } \\
\text { I-DF }\end{array}$ & $\begin{array}{r}\text { WF05-B- } \\
11 \text {-DF }\end{array}$ & $\begin{array}{l}\text { MF06-T- } \\
\text { III-OF }\end{array}$ & $\begin{array}{r}\text { HFO7-B- } \\
1-D F\end{array}$ & $\begin{array}{r}\text { WF08-T- } \\
\text { II-DF }\end{array}$ & $\begin{array}{l}\text { WFO9-B } \\
\text { III-DF }\end{array}$ & $\begin{array}{r}\text { WF 10-7- } \\
\text { 1-DF }\end{array}$ & $\begin{array}{r}\text { WF 11-B- } \\
\quad 11-D F\end{array}$ \\
\hline CL2(08) & No & ND & No & HD & 0.44 & HD & ND & ND & 0.12 & ND & 0.25 & 0.90 & 0.36 \\
\hline $\mathrm{Cl} 3(18)$ & HD & ND & 0.27 & 2.51 & 2.83 & 0.29 & 6.33 & 0.19 & 0.07 & 9.20 & 1.04 & 4.55 & 0.61 \\
\hline CL3(28) & HO & MD & 0.20 & 17.94 & 34.47 & 2.68 & 176.38 & 1.39 & 0.43 & 76.33 & 2.77 & 26.80 & 0.68 \\
\hline $\operatorname{cl4}(52)$ & ND & ND & 0.30 & 8.26 & 11.64 & 0.60 & 9.96 & 0.88 & 0.30 & 46.23 & 2.90 & 8.51 & 1.02 \\
\hline$C L 4(44)$ & HD & 0.95 & 0.33 & 2.35 & 1.47 & 0.29 & 1.22 & 0.30 & 0.11 & 3.05 & 1.17 & 1.61 & 0.42 \\
\hline$C 16(66)$ & HD & ND & 0.24 & 72.80 & 52.51 & 5.45 & 360.91 & 2.93 & 0.87 & 86.89 & 6.18 & 35.42 & 1.14 \\
\hline $\operatorname{CLS}(101)$ & ND & ND & 0.43 & 22.31 & 25.11 & 4.04 & 36.49 & 3.80 & 1.02 & 46.95 & 4.64 & 8.09 & 0.82 \\
\hline $\operatorname{CLS}(118)$ & No & ND & 0.75 & 405.48 & 158.80 & 12.64 & 769.88 & 6.79 & 1.76 & 199.68 & 22.49 & 50.02 & 1.62 \\
\hline$C L 6(153)$ & ND & ND & 1.32 & 526.54 & 154.28 & 11.15 & 586.33 & 6.47 & 3.09 & 232.43 & 25.06 & 54.24 & 2.61 \\
\hline CLS(105) & ND & ND & 0.16 & 72.07 & 40.55 & 2.71 & 105.63 & 1.18 & 0.48 & 45.51 & 5.04 & 21.84 & 0.47 \\
\hline$C L 6(138)$ & HD & ND & 0.87 & 437.00 & 129.89 & 10.13 & 426.59 & 5.97 & 2.55 & 189.22 & 20.91 & 46.84 & 2.02 \\
\hline $\operatorname{cL}(187)$ & ND & ND & 0.27 & 6.19 & 5.05 & 0.61 & 13.78 & 0.42 & 1.01 & 8.81 & 1.14 & 4.85 & 0.44 \\
\hline$C L 6(128)$ & ND & ND & 0.05 & 79.50 & 24.60 & 1.51 & 23.17 & 0.26 & 0.38 & 12.38 & 2.75 & 9.93 & 0.29 \\
\hline $\operatorname{cL}(180)$ & HD & ND & 0.21 & 72.84 & 24.58 & 1.24 & 48.77 & 0.46 & 1.44 & 23.15 & 3.09 & 11.57 & 0.81 \\
\hline $\operatorname{cl} 7(170)$ & NO & 3.45 & 0.39 & 39.23 & 15.23 & 0.79 & 26.93 & 0.39 & 0.45 & 14.65 & 2.61 & 9.49 & 0.17 \\
\hline CL8(195) & NO & ND & 0.03 & 3.27 & 0.89 & 0.08 & 1.92 & MD & 0.35 & 0.96 & 0.22 & 1.25 & 0.09 \\
\hline$C L 9(206)$ & ND & ND & 0.01 & 1.91 & 0.59 & 0.06 & ND & ND & 0.47 & 0.95 & 0.17 & 1.00 & 0.11 \\
\hline$C L 10(209)$ & NO & ND & 0.08 & ND & 0.13 & 0.04 & ND & ND & 0.39 & ND & 0.15 & 0.31 & 0.21 \\
\hline Sum of 18 Congeners & ma & ma & 5.90 & 1770.19 & 683.15 & 54.31 & 2614.30 & 31.40 & 15.27 & 996.38 & 102.50 & 297.14 & 13.88 \\
\hline Total PCB & MA & MA & 10.17 & 3052.04 & 1177.85 & 93.64 & 4507.42 & 54.14 & 26.33 & 1717.89 & 176.73 & 512.30 & 23.93 \\
\hline Sum of 17 Congeners & MA & ma & 5.51 & 1730.96 & 667.93 & 53.52 & 2587.37 & 31.01 & 14.82 & 981.73 & 99.89 & 287.73 & $13.7 t$ \\
\hline Totel PCB & MA & HA & 9.61 & 3020.87 & 1165.67 & 93.40 & 4515.47 & 54.12 & 25.86 & 1713.31 & 174.33 & 502.15 & 23.92 \\
\hline
\end{tabular}

PCB Concentration changes in cooked Seafood

Phose 1: Winter flounder

Project Number: G1969-0005

Data reported in $\mathrm{ng} / \mathrm{g}$ pre-cooked wet weight (procedural blank reported in total $\mathrm{ng}$ ).

The procedural blank JG24PB was processed with up07, 10, 11, 14, and 21. J173PB was processed with the rest of the samples.

The sum of the 17 is the sum of all listed PCB congeners excluding CL7(170). 
TABLE A.3. (contd)

Battelle ocean Sciences

File: PCB_DF

Val idated:

\section{Created: GSD 06/11/91}

Edited:

$\begin{array}{rrrr}\text { WF12-T- } & \text { WF13-8- } & \text { WF } 14-T- & \text { UF } 15-8- \\ 111-\mathrm{OF} & 1-\mathrm{DF} & 11-\mathrm{DF} & 111-\mathrm{DF}\end{array}$

Sample 10

CL2(08)

CL3(18)

CL3(28)

CL4(52)

CL.4(44)

CL4(66)

CLS(101)

CL5(118)

CL6(153)

CLS(105)

CL6(138)

CL7(187)

CL6(128)

CL7(180)

CL7(170)

CLB( 195)

CL.9(206)

CL10(209)

Sum of 18 Congeners

rotal PCB

Sum of 17 Congeners

Total PCB

$$
\begin{array}{r}
3.53 \\
11.38 \\
156.01 \\
22.67 \\
4.32 \\
183.80 \\
57.51 \\
293.79 \\
227.36 \\
56.84 \\
183.06 \\
7.48 \\
26.92 \\
18.52 \\
11.72 \\
1.07 \\
\text { ND } \\
\text { ND } \\
\\
1265.98 \\
2182.72
\end{array}
$$

0.17$$
\begin{aligned}
& 0.24 \\
& 0.87
\end{aligned}
$$$$
0.77
$$$$
\begin{aligned}
& 0.40 \\
& 1.47
\end{aligned}
$$$$
\begin{aligned}
& 1.47 \\
& 1.83
\end{aligned}
$$$$
3.57
$$$$
\begin{aligned}
& 3.57 \\
& 4.80
\end{aligned}
$$$$
\begin{aligned}
& 4.80 \\
& 0.51
\end{aligned}
$$$$
\begin{aligned}
& 0.51 \\
& 3.99
\end{aligned}
$$$$
\begin{aligned}
& 0.41 \\
& 0.35
\end{aligned}
$$$$
\begin{aligned}
& 0.35 \\
& 0.46 \\
& 0.52
\end{aligned}
$$$$
0.04
$$$$
0.04
$$$$
\begin{aligned}
& 0.03 \\
& 0.02
\end{aligned}
$$$$
0.21
$$$$
0.35
$$$$
0.63
$$$$
0.79
$$$$
\begin{aligned}
& 0.35 \\
& 0.93
\end{aligned}
$$$$
0.93
$$$$
\begin{aligned}
& 0.79 \\
& 1.27
\end{aligned}
$$$$
\begin{aligned}
& 1.92 \\
& 0.36
\end{aligned}
$$$$
1.62
$$$$
\begin{aligned}
& 1.38-3.53 \\
& 0.36
\end{aligned}
$$$$
\begin{array}{ll}
0.57 & 0.56
\end{array}
$$$$
0.15 \quad 0.65
$$$$
0.10 \quad 0.05
$$$$
0.12
$$$$
0.29
$$

HD
ND
0.38$$
0.26
$$

\begin{tabular}{|c|c|c|c|c|c|}
\hline $\begin{array}{l}\text { UF 16-T- } \\
\qquad-D F\end{array}$ & $\begin{array}{r}\text { UF } 17-8- \\
11-O F\end{array}$ & $\begin{array}{l}\text { UF 18-T } \\
\text { III-DF }\end{array}$ & $\begin{array}{r}\text { UF 19-B- } \\
1-D F\end{array}$ & $\begin{array}{r}\text { WF 20-T- } \\
\text { II-DF }\end{array}$ & $\begin{array}{l}\text { WF21-B- } \\
\text { III-OF }\end{array}$ \\
\hline 0.26 & No & ND & 0.07 & 0.25 & 0.88 \\
\hline 0.71 & ND & 0.82 & 0.04 & 0.85 & 1.25 \\
\hline 1.12 & 6.83 & 12.03 & 0.78 & 4.65 & 5.36 \\
\hline 1.03 & 6.25 & 3.87 & 0.12 & 3.27 & 3.61 \\
\hline 0.61 & ND & 0.78 & 0.12 & 1.05 & 1.11 \\
\hline 1.55 & 29.99 & 65.29 & 2.69 & 14.53 & 12.98 \\
\hline 1.47 & 49.87 & 24.74 & 0.72 & 14.74 & 9.52 \\
\hline 5.51 & 137.80 & 404.70 & 10.31 & 69.13 & 27.24 \\
\hline 8.46 & 159.16 & 397.68 & 10.44 & 66.94 & 28.81 \\
\hline 0.74 & 15.22 & 40.65 & 1.73 & 13.33 & 9.70 \\
\hline 6.08 & 135.18 & 294.02 & 9.98 & 64.31 & 27.28 \\
\hline 0.44 & 8.46 & B.27 & 0.67 & 4.58 & 3.56 \\
\hline 0.29 & 5.78 & 14.56 & 0.74 & 3.48 & 5.33 \\
\hline 0.87 & 15.32 & 43.52 & 1.27 & 11.29 & 6.78 \\
\hline 0.60 & 11.75 & 29.27 & 0.94 & 7.33 & 4.25 \\
\hline 0.04 & ND & 1.48 & 0.08 & 0.46 & 0.64 \\
\hline 0.03 & ND & 1.08 & 0.07 & 0.29 & 0.52 \\
\hline ND & ND & ND & 0.04 & 0.10 & 0.24 \\
\hline 29.60 & 581.60 & 1342.54 & 40.80 & 280.58 & 149.06 \\
\hline 51.03 & 1002.76 & 2314.73 & 70.34 & 483.76 & 256.99 \\
\hline 28.99 & 569.85 & 1313.27 & 39.86 & 273.25 & 144.80 \\
\hline 50.60 & 994.50 & 2291.92 & 69.56 & 476.87 & 252.71 \\
\hline
\end{tabular}$$
\begin{aligned}
& 0.22 \\
& 0.75
\end{aligned}
$$$$
1.09
$$$$
\begin{aligned}
& 3.09 \\
& 4.51
\end{aligned}
$$$$
\begin{aligned}
& 4.51 \\
& 0.48
\end{aligned}
$$$$
20.46
$$$$
11.09
$$$$
19.11
$$

1254.25

19.94
34.80

10.94
19.08$$
\begin{array}{ll}
0.36 & 0.55 \\
0.29 & 0.22
\end{array}
$$

PCB Concentration Changes in Cooked Seafood

Phase 1: Uinter flounder

Project Number: G1969-0005

Data reported in ng/g pre-cooked wet weight (procedural blank reported in total ng). 
TABLE A.4. PCB Concentrations in the Pan-Fried Samples

Bottelle Ocean Sciences

Flle: PCB PF

Vol idated:

Sample 10

C.2(08)

CL3(18)

CL3(28)

CL4(52)

$C(4(44)$

$\mathrm{CL} 4(66)$

C.5(101)

CL5(118)

CL5(105)

CL6(138)

Cl7(187)

CL6(128)

CL7(180)

CL7(170)

CL8(195)

CL9(206)

CL 10(209)

Sum of 18 congeners

Total PCB

Sun of 17 Congeners

Total PCB
Created: GSO 06/11/91 Edited:
PCB Concentration changes in cooked seafood

Phose 1: Vinter flounder

Project Number: 61969-0005

Doto reported in $\mathrm{ng} / \mathrm{g}$ pre-cooked wet weight (procedural blank reported in total $\mathrm{ng}$ ).

JG'24P

J179PB WF01.B- WF02.1-

$$
\begin{aligned}
& \text { WF01-B- } \\
& 11 \cdot P F \quad 111 \cdot P F
\end{aligned}
$$

WF 03-B-
I-PF

WFO6-T.
II.PF

WF 05-B-

WF06-I -

WFO7-B-

WFOB-T -

WF09-8

WF 10- T-

UF $11-8-$

ND $\quad 0.55$

0.32

\section{MP}

I.PF

0.76 III-PF

I-PF

$11 \cdot \mathrm{PF}$

II-PF

$\begin{array}{rrrr}\text { ND } & 0.17 & 3.55 & 2.60 \\ \text { ND } & 0.19 & 26.86 & 25.53 \\ \text { NO } & 0.30 & 10.24 & 9.35 \\ 0.50 & 0.12 & 1.19 & 1.17 \\ \text { ND } & 0.14 & 103.86 & 36.06\end{array}$

$0.51 \quad 11.61$

$5.57 \quad 396.81$

$1.50 \quad 97.74$

0.20

0.76 ND

0.38

0.42138 .42

1.82
2.44

2.35

1.98

$0.34 \quad 2.60$
17.81

1.02

$0.56-63.24$

2.44
3.66

33.04

1.68
$0.14 \quad 103.86$
38.06

17.81778 .26

$\begin{array}{lr}0.39 & 29.49 \\ 0.60 & 564.08\end{array}$

17.90

12.75

0.25

4.63

0.75

3.87

1.65

157.76

9.8374 .70

7.30

6.11
30.05

11.52

689.59

100.93

$\begin{array}{ll}40.56 & 1738.49\end{array}$

$0.11 \quad 97.67$

27.28

$13.57 \quad 333.11$

11.17

353.96

30.05

$0.98 \quad 363.73 \quad 36.14$

4.980327 .48

6.14
28.42
1.64

$\begin{array}{rrrrr}0.78 & 578.91 & 83.59 & 44.69 & 999.68 \\ 0.19 & 7.69 & 3.26 & 3.06 & 30.91\end{array}$

$44.69 \quad 999.68$

$0.03 \quad 108.98$

14.98

6.3960 .75

12.02

0.92

9.72

$\begin{array}{lll}0.76 & 27.01 & 4.20 \\ 2.66 & 41.06 & 3.73\end{array}$

$05.12 \quad 15.38$

125.61

$4.31 \quad 73.84$

$\begin{array}{lll}3.96 & 0.22 & 57.57\end{array}$

$\begin{array}{lll}0.03 & 4.15 & 0.67\end{array}$

0.03
0.03

2.88

0.47
0.14

$0.47 \quad 3.91$

0.08

41.06

$\begin{array}{lll}0.86 & 26.81 & 3.32\end{array}$

$0.58 \quad 1.8$

3.32
0.40

No 0.03

0.18

2.62
ND

0.04

0.57

ND

0.39
0.28

9.81

1.52

$10.66 \quad 2.26$

$60.53 \quad 5.16$

$60.82 \quad 6.84$

$24.63 \quad 1.30$

$50.08 \quad 5.47$

$\begin{array}{rl}5.50 & 1.20\end{array}$

$11.00 \quad 0.93$

$13.48 \quad 2.45$

$\begin{array}{ll}1.47 & 0.25\end{array}$

$\begin{array}{ll}1.47 & 0.25 \\ 1.37 & 0.28\end{array}$

ma

MA $\quad 4.52$

$2372.35 \quad 456.45$

$211.84 \quad 5860.86$

53.14

$27.44 \quad 1687.11$

137.14

0.37

0.21

$365.24 \quad 10139.07$

53.14
91.62

47.31

2908.81

236.44

345.44

39.06

$\begin{array}{rr}207.53 & 5806.82 \\ 362.19 & 10134.08\end{array}$

52.10
90.93

26.58
46.39

1660.30
2897.55

133.82

334.73

The procedural blank JG24PB was processed with UPOT, 10, 11, 14, and 21. J179PB was processed with the rest of the samples.

The sum of the 17 is the sum of all listed PCB congeners excluding CL7(170). 
TABLE A.4. (contd)

Battelle Ocean Sciences

File: PCB PF

Val idated:

Created: GSD 06/11/91 Edited:

WF12-T - WF13-8-

Sample ID

CL3(18)

$\mathrm{CL3}(28)$

$\mathrm{CL} 4(52)$

CL4(44)

CL4(66)

CL5(101)

CLS(118)

$C L 6(153)$
$\quad C L 5(105)$

CL6(138)

CL7(187)

CL6(128)

CL7(180)

CL7(170)

CLB(195)

CL9(206)

CL.10(209)

Sun of 18 Congeners Total PCB

Sum of 17 Congeners

Total PCB
5350.39

6.60

18.41

320.00

38.92

7.41

445.43

126.00

510.38

205.87

484.83

18.98
87.66

57.75

35.43

2.38

1.83

HD

3067.80

5353.92
I1-PF

\subsection{2}

0.45

1.26

2.17

0.54

3.11

5.69

13.76

20.38

2.70

19.02

2.16

1.89

2.67

2.04

0.24

0.19

0.10

78.68

135.66

76.65

133.76
UF $14-T-$

$$
1.66
$$

0.85

1.73

1.35

0.86

2.16

1.76

3.08

4.37

0.88

3.67

0.84

0.74

1.31

0.31

0.24

0.30

0.43

26.54

45.77

26.23

45.78
WF $15-8-$

1-PF

MD

0.05

0.17

0.21
0.15

0.47

0.81

2.22

0.29

2.92

0.56

0.18

0.40

0.43

0.07

0.06

0.05

12.69

21.88

12.26

21.40
3.67
PCB Concentration Changes in Cooked Seafood

Phase 1: Ninter Flounder

Project Number: G1969-0005

Data reported in $\mathrm{ng} / \mathrm{g}$ pre-cooked wet weight (procedural blank reported in total $\mathrm{ng}$ ).

$$
11-P F
$$

III-PF

0.40

0.83

NO
1.59
28.84

28.84
17.96

1.35

121.74

153.12

497.91

461.43

60.69

475.38

24.53

24.83

51.32

35.81

2.01

1.05

ND

1959.55

47.33

81.60

3378.54

46.05

80.37

1923.75

3357.32
WF 18-T-
I-PF

19-8-

II-PF III-PF

WF21-8

ND
0.52

.0 .17

0.07

0.19

0.13

5.11

1.12

20.84

21.84

3.37

21.85

194.66

5.59

10.35

1.46
1.76
2.88

2.88

1.93
0.19

0.19

0.15
0.09

8.

879.68

1516.68

84.25

145.25

861.92

82.32

143.66

458.7

800.61
III-PF

ND
1.65

6.86

1-PF

1.87

1.36

4.94

3.55

1.03

$23.85 \quad 11.84$

$25.98 \quad 7.98$

$115.81 \quad 22.94$

$118.49 \quad 26.18$

$19.82 \quad 9.10$

$107.38 \quad 25.92$

$7.56 \quad 3.44$
5.06

$5.06 \quad 4.92$

$18.28 \quad 6.23$

$12.24 \quad 4.32$

$0.68 \quad 0.70$

$0.37 \quad 0.70$

$0.10 \quad 0.26$

137.27

236.67

132.95

232.02 


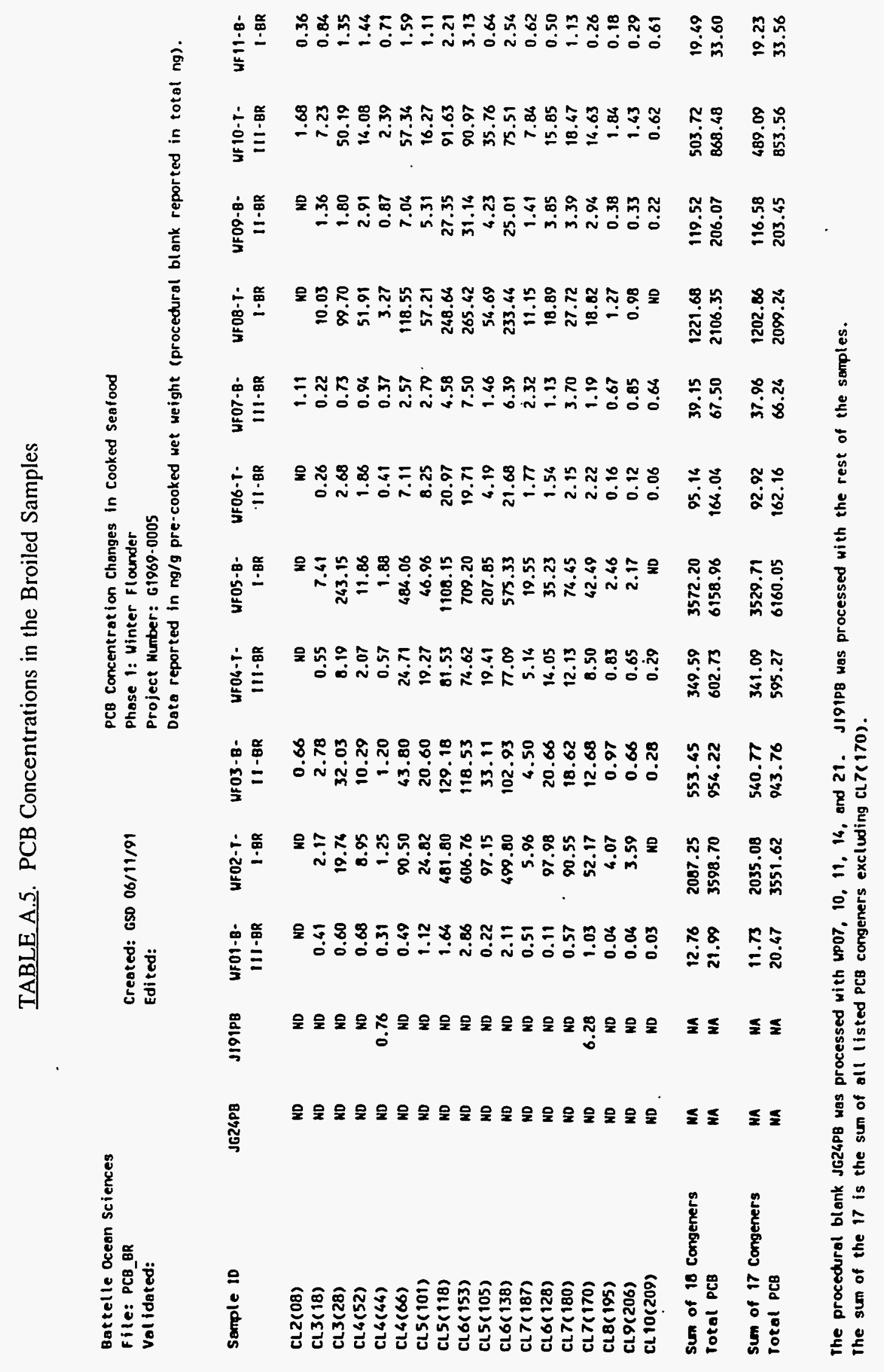




\begin{tabular}{|c|c|c|c|c|c|c|c|c|c|c|c|}
\hline $\begin{array}{l}90.672 \\
1<.271\end{array}$ & $\begin{array}{l}25^{\circ} .885 \\
95^{\circ} \cdot 755\end{array}$ & $\begin{array}{l}99^{\circ} 692 \\
90^{\circ} \varepsilon 71\end{array}$ & $\begin{array}{l}66^{\circ} 5162 \\
98^{\circ} 0291\end{array}$ & $\begin{array}{l}52^{\circ} \text { ESSL } \\
75.8 \angle 8\end{array}$ & $\begin{array}{l}52.05 \\
76.55\end{array}$ & $\begin{array}{l}60.82 \\
01.91\end{array}$ & $\begin{array}{l}78 \cdot 07 \\
09 \cdot 52\end{array}$ & $\begin{array}{l}9 l^{\circ} 281 \\
85^{\circ} .01\end{array}$ & $\begin{array}{l}89.51 \angle 5 \\
\angle 6.7225\end{array}$ & SJPUP6LNoJ & $\begin{array}{l}\text { 9Jd } 10201 \\
21 \text { to uns }\end{array}$ \\
\hline $\begin{array}{l}25 \cdot 252 \\
15 \cdot 291\end{array}$ & $\begin{array}{l}88^{\circ} 265 \\
28^{\circ} \varepsilon 75\end{array}$ & $\begin{array}{l}15^{\circ} 752 \\
05^{\circ} 271\end{array}$ & $\begin{array}{l}58 \cdot 8562 \\
25 \cdot 90 \angle 4\end{array}$ & $\begin{array}{l}06^{\circ} \text { S7SL } \\
29^{\circ} 988\end{array}$ & $\begin{array}{l}29 \cdot 09 \\
61 \cdot 55\end{array}$ & $\begin{array}{l}58 \cdot 05 \\
88.26\end{array}$ & $\begin{array}{l}28 \cdot 09 \\
89.12\end{array}$ & $\begin{array}{l}86^{\circ} 981 \\
57^{\circ} 801\end{array}$ & $\begin{array}{l}72 \cdot 0695 \\
75 \cdot 0055\end{array}$ & Ssมuว640J & $\begin{array}{l}\text { gJd } 10301 \\
81 \text { to uns }\end{array}$ \\
\hline $12 \cdot 0$ & $81^{\circ} 0$ & 80.0 & OH & ON & so.0 & So.0 & $8 \Sigma^{\circ} 0$ & $1 l^{\circ} 0$ & ON & & $(602) 0170$ \\
\hline SS.0 & $15^{\circ} 0$ & $61^{\circ} 0$ & $29 \% 1$ & $\angle L^{\circ} 0$ & $80 \% 0$ & E0.0 & $0 E^{\circ} 0$ & $22^{\circ} 0$ & $87 \cdot 1$ & & $(902) 675$ \\
\hline $89^{\circ} 0$ & $S L^{\circ} O$ & $82^{\circ} 0$ & 27.2 & $61 \cdot 1$ & $60 \%$ & 20.0 & $61 \cdot 0$ & $O E^{\circ} 0$ & $15^{\circ} !$ & & $(561) 870$ \\
\hline $08^{\circ} y$ & $15^{\circ} 6$ & $27 \cdot 3$ & $99^{\circ} \mathrm{CK}$ & 80.81 & $92 \% 1$ & $82 \cdot 1$ & $82 \cdot 0$ & $20^{\circ}$ & $\angle E^{\prime} S Z$ & & $(0<1)<75$ \\
\hline $66^{\circ} 9$ & $5 l \cdot 2 l$ & $02 \cdot 5$ & $\angle B^{\circ} 97$ & $08 \cdot 22$ & IE.' & $57^{\circ} 0$ & 61.1 & $85^{\circ} \varepsilon$ & $18 \cdot 94$ & & $(081)<73$ \\
\hline 72.5 & $56^{\circ} \mathrm{E}$ & $62^{\circ} \Sigma$ & $S L=81$ & $02^{\circ} \mathrm{El}$ & 370 & $22^{\circ} 0$ & $89 \div 0$ & $59 \cdot 2$ & $38 \% 11$ & & כ כ \\
\hline $9 S^{\circ} \varepsilon$ & $\angle L 5$ & $99 \cdot 2$ & $S L^{\circ} \mathrm{OL}$ & $61 \cdot 21$ & $59^{\circ} 0$ & 29.0 & $06^{\circ} 0$ & $50^{\circ} 2$ & $57^{\circ} 21$ & & $(\angle 81)<73$ \\
\hline $69^{\circ} 92$ & $00^{\circ} 62$ & $1 \varepsilon^{\circ} 8 \varepsilon$ & $86^{\circ} 72 \varepsilon$ & $29 \cdot 812$ & $5 t \cdot 8$ & $1 / \cdot \varepsilon$ & $6 l \cdot \varepsilon$ & $\angle 2 \cdot 92$ & $55 \cdot 297$ & & $(856) 973$ \\
\hline 15.6 & $65^{\circ} 71$ & $9 L^{\circ} 9$ & 58.67 & 50.22 & $91 \cdot 1$ & $5 \% \cdot 0$ & $28 \cdot 0$ & $19^{\circ} \varepsilon$ & 29.651 & & (sol)s \\
\hline$\angle L \angle 2$ & $09^{\circ} \varepsilon 8$ & $68^{\circ} 55$ & 62.205 & $82 \cdot 822$ & $72 \cdot 6$ & $08 \% 7$ & $\angle 9^{\circ} \mathrm{E}$ & $02 \cdot 12$ & $6 \varepsilon^{\circ} 255$ & & (ESI)97J \\
\hline 75.92 & $18^{\circ} 98$ & $\angle 7^{\circ} 95$ & $5 \% 805$ & $88^{\circ} \angle 12$ & $9 \Sigma^{\circ} 9$ & $70^{\circ} \varepsilon$ & $15^{\circ} \mathrm{E}$ & 70.61 & $6 L^{\circ} S S L$ & & $(841) S 73$ \\
\hline 07.6 & 77.81 & $16 \%$ & 56.15 & $11 \cdot 69$ & $\angle H^{\circ} 1$ & $61 \cdot 1$ & 67.1 & 85.2 & $65^{\circ} 05$ & & $(101) 570$ \\
\hline$S L=2 !$ & $81 \cdot 2 l$ & $55^{\circ} 6$ & $05^{\circ} 88$ & $92 \circ O S$ & 571 & $89^{\circ} 0$ & $88 \cdot 1$ & $25 \%$ & IE'SSS & & $(99) \geqslant 73$ \\
\hline $90^{\circ} !$ & $90 \% 1$ & $12^{\circ} 0$ & $59^{\circ} 0$ & $00^{\circ} 1$ & 17.0 & $22^{\circ} 0$ & $S L \cdot 0$ & $\angle 5^{\circ} 0$ & 10.6 & & כ כרד) \\
\hline $98^{\circ} \mathrm{E}$ & $66^{\circ} 7$ & OE. 0 & $6 E^{\circ} 5$ & $22 \cdot 8$ & $66^{\circ} 0$ & $\varepsilon 2^{\circ} 0$ & SE: : & $59 \cdot 2$ & $59^{\circ} 87$ & & כ25)》(25) \\
\hline $25^{\circ} 5$ & $22 \% 5$ & $98 \%$ & $6 \varepsilon^{*} 22$ & $50 \% 16$ & $08^{\circ} 0$ & $22^{\circ} 0$ & $8 \varepsilon^{\circ} !$ & $39 \%$ & $11 \cdot 207$ & & $(82) \varepsilon 7 J$ \\
\hline $9 \varepsilon * 1$ & $21 \cdot 1$ & $21 \cdot 0$ & $82^{\circ} 0$ & $26^{\circ} 0$ & $85 \%$ & $80^{\circ} 0$ & EB*0 & $15^{\circ} 0$ & $3 E^{\circ} \cdot 32$ & & $(86) \varepsilon 73$ \\
\hline 50.1 & $7 E^{\circ} 0$ & $61^{\circ} 0$ & ON & an & $52 \cdot 0$ & OH & $16^{\circ} 0$ & ON & 36.2 & & כוב) \\
\hline $48-11$ & $88-1$ & 48-111 & $88-11$ & $88-1$ & 88.111 & $88-11$ & $88-1$ & $88-111$ & $8 \theta-11$ & & \\
\hline$-8-12 J n$ & $-1-02 \exists H$ & $-0.61 \mathrm{JH}$ & $-1-81 \mathrm{JM}$ & $-8-2 l d n$ & $-1-9 l \mathrm{Jn}$ & $-\theta \cdot S t+A n$ & $-1-\eta 1 \mathrm{Jn}$ & $-\theta-\varepsilon l J n$ & $-1-21 \mathrm{An}$ & & of $ә$ duos \\
\hline
\end{tabular}

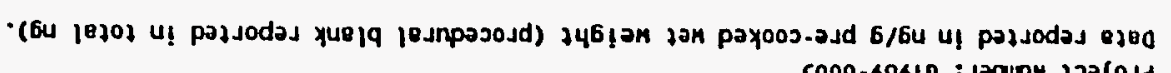

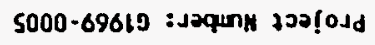


TABLE A.6. Treatment Section Pre- and Post-Cooking Weight, and Extraction Sample Weight

\begin{tabular}{|c|c|c|c|c|}
\hline \multicolumn{3}{|c|}{$\begin{array}{l}\text { BATTELLE OCEAN SCIENCES } \\
\text { Soved os: SIZE } \\
\text { Entered by: B.KOCzworo 05/02/91 } \\
\text { Validored: }\end{array}$} & $\begin{array}{r}\text { Flounder Stux } \\
=\$: 01969-000 \text { ? } \\
\text { G1969-000 }\end{array}$ & \\
\hline & SAMPLE SEC & ON VEIGHT (g) & EXTRACTION & SAMPLE WEIGHT (g) \\
\hline SAMPLE ID & PRE-COOKIHG & POST-COOKING & WEIGHT USED & PRE-COOKING EQUIVALENT \\
\hline WFOI -UK & MA & NA & 25.2 & 25.2 \\
\hline WFO1-B-1-DF & 27.2 & 29.1 & 12.7 & 16.3 \\
\hline WFO1-B-11-PF & 33.4 & 30.4 & 17.0 & 18.7 \\
\hline $4 F 01-8-111-B R$ & 15.5 & 14.1 & 10.1 & 11.1 \\
\hline WFO2-UN & ma & MA & 5.4 & 5.4 \\
\hline WFOZ-T-1-BR & 13.2 & 91.1 & 7.0 & 8.3 \\
\hline WFO2-T-II-DF & 22.6 & 14.9 & 9.0 & 13.6 \\
\hline WFO2-T-III-PF & 12.2 & 10.5 & 6.1 & 7.1 \\
\hline WF03-UN & MA & MA & 9.9 & 9.9 \\
\hline WFO3-B-I-PF & 9.1 & 8.5 & 4.4 & 4.8 \\
\hline $4 F 03-8-11-8 R$ & 13.5 & 11.8 & 8.2 & 9.4 \\
\hline MFO3-8-111-DF & 19.5 & 8.1 & 4.2 & 6.0 \\
\hline HFO4-UN & ma & Wh & 7.7 & $7: 7$ \\
\hline HFOA-T-I-OF & 16.3 & 10.2 & 5.6 & 8.9 \\
\hline$H F Q_{4}-T \cdot I I-P F$ & 16.9 & 16.3 & 10.1 & 90.5 \\
\hline WFO4-T-III-BR & 15.7 & 16.5 & 8.4 & 9.1 \\
\hline WF05-UN & NA & MA & 6.1 & 6.1 \\
\hline UF05-B-1-BR & 16.2 & 14.4 & 8.7 & 9.7 \\
\hline WFOS-B-11-DF & 94.2 & 9.1 & 4.9 & 7.7 \\
\hline WF05-B-III-PF & 10.7 & 10.1 & 6.1 & 6.4 \\
\hline WFOS-UK & WA & WA & 20.9 & 20.9 \\
\hline WFOS-T-1-PF & 21.3 & 29.3 & 13.5 & 13.5 \\
\hline UFOS-T-1I-BR & 22.5 & 29.0 & 14.6 & 95.4 \\
\hline UFOS-T-III-DF & 17.3 & 10.8 & 6.7 & 90.7 \\
\hline UF07-UK & $\mathrm{HA}$ & MA & 25.1 & 25.1 \\
\hline HFO7-B-I-DF & 25.2 & 15.7 & 7.1 & 11.4 \\
\hline$W F 07-B \cdot 11-P F$ & 23.9 & 22.7 & 14.1 & 14.9 \\
\hline WF07-B-111-BR & 22.9 & 21.5 & 13.6 & 14.4 \\
\hline UFOS-UK & MA & MA & 5.6 & 5.6 \\
\hline UFOS-T-I-BR & 26.2 & 20.9 & 15.0 & 18.8 \\
\hline UFOS-T-1I-DF & 23.9 & 13.7 & 7.8 & 93.7 \\
\hline HFOS-T-III-PF & 20.6 & 18.4 & 10.5 & 19.8 \\
\hline WF09-UN & Na & HA & 11.0 & 11.0 \\
\hline$M F O Q-B-I-P F$ & 6.5 & 6.3 & 3.7 & 3.8 \\
\hline$U F 09-B-11-B R$ & 7.8 & 6.0 & 3.5 & 4.6 \\
\hline$U F O Q-B-I 1 I-D F$ & 8.5 & 4.1 & 2.4 & 5.0 \\
\hline UF $10-$ UN & NA & $\mathrm{Mh}$ & 25.3 & 25.3 \\
\hline HF 10-T-I-DF & 23.2 & 15.2 & 8.1 & 12.4 \\
\hline UF 10-T-II-PF & 21.8 & 19.8 & 12.3 & 93.5 \\
\hline HF $10-T-I I I-B R$ & 21.0 & 17.4 & 10.4 & 12.6 \\
\hline
\end{tabular}


TABLE A.6. (contd)

\begin{tabular}{|c|c|c|c|c|}
\hline \multirow[b]{2}{*}{ SAMPLE IO } & \multicolumn{2}{|c|}{ SAMPLE SECTION WEIGHT (g) } & \multicolumn{2}{|c|}{ EXTRACTION SAMPLE WEIGHT (g) } \\
\hline & PRE-COOXING & POST-COOKING & WEIGHT USED & PRE-COOKING EQUIVALENT \\
\hline WF11-UK & MA & HA & 20.1 & 20.1 \\
\hline HF11-B-I-BR & $\$ 1.6$ & 8.3 & 5.1 & 7.1 \\
\hline$W F I I-B-I I-D F$ & 10.7 & 5.9 & 3.1 & 5.6 \\
\hline WF $11-8-111-P F$ & 9.1 & 8.8 & 5.1 & 5.3 \\
\hline WF 12-UN & MA & NA & 5.9 & 5.9 \\
\hline WF12-7-1-PF & 16.3 & 14.85 & 10.1 & 11.1 \\
\hline WF 12-T-II-BR & 11.8 & 9.9 & 6.7 & 7.9 \\
\hline HFI2-T-III-DF & 97.0 & 10.0 & 5.3 & 9.0 \\
\hline WF 13-UN & MA & $\mathrm{ma}$ & 20.1 & 20.1 \\
\hline WF 13-8-I-DF & 20.8 & 9.6 & 6.0 & 13.1 \\
\hline$W F 13-B-I 1-P F$ & 16.5 & 95.4 & 10.0 & 10.7 \\
\hline$M F 13-B-111-B R$ & 17.1 & 11 & 5.6 & 8.6 \\
\hline NF14-UN & NA & NA & 20.1 & 20.1 \\
\hline WF14-T-I-BR & 14.6 & 11.9 & 7.3 & 9.0 \\
\hline WF $14-T-I I-D F$ & 13.9 & 8.5 & 4.7 & 7.6 \\
\hline WF 14-T-IIII-PF & 10.9 & 9.2 & 5.9 & 7.0 \\
\hline UF15-UK & KA & NA & 14.4 & 14.4 \\
\hline WF15-B-1-PF & 12.8 & 11.1 & 7.0 & 8.1 \\
\hline$W F 15-B-11-B R$ & 10.8 & 9.9 & 5.9 & 6.5 \\
\hline$U F 15-B-I I I-D F$ & 10.3 & 5.0 & 2.6 & 5.3 \\
\hline UF 16-UK & NA & NA & 20.3 & $20: 3$ \\
\hline WF 16-T-I-DF & 24.3 & 14.1 & 8.0 & 13.8 \\
\hline WF $16-T-11 \cdot$ PF & 26.7 & 26.2 & 16.7 & 17.0 \\
\hline WF $16-T-111-B R$ & 22.0 & 17.4 & 10.5 & 13.3 \\
\hline WF 17-UW & MA & MA & 10.7 & 10.7 \\
\hline HF 17-B-I-BR & 18.2 & 16.2 & 10.2 & 11.4 \\
\hline WF $17-B-11-D F$ & 19.1 & 8.2 & 4.7 & 10.9 \\
\hline WF $17 \cdot B-I I I \cdot P F$ & 25.0 & 23.9 & 15.2 & 15.8 \\
\hline WF18-UK & HA & MA & 5.6 & 5.6 \\
\hline UF18-T-I-PF & 21.8 & 19.7 & 14.3 & 15.8 \\
\hline WF18-T-II-BR & 27.0 & 24.3 & 15.7 & 17.4 \\
\hline WF 18-T-III-DF & 17.4 & 10.0 & 6.0 & 10.4 \\
\hline HF19-UH & MA & MA & 20.7 & 20.7 \\
\hline$W F 19-B-1-D F$ & 36.4 & 22.7 & 12.3 & 19.7 \\
\hline UF 19-B-11-PF & 24.6 & 20.9 & 12.7 & 15.0 \\
\hline WF 19-B-III-BR & 13.4 & 10.1 & 7.1 & 9.4 \\
\hline WF20-UH & MA & NA & $10: 3$ & 10.3 \\
\hline HFZO-T-I-BR & 30.4 & 27.9 & 12.2 & 13.3 \\
\hline$W F 20-T-11 \cdot D F$ & 36.4 & 24.2 & 90.0 & 15.1 \\
\hline WF20-T- $111-P F$ & 32.4 & 30.8 & 7.6 & 8.0 \\
\hline WF21-UN & Ma & MA & 25.0 & 25.0 \\
\hline AF21-B-I-PF & 41.4 & 40.1 & 20.2 & 20.8 \\
\hline WF21-B-II-BR & 44.9 & 40.3 & 20.6 & 23.0 \\
\hline WF21-B-III-DF & 32.6 & 20.4 & 13.1 & 21.0 \\
\hline
\end{tabular}

Pre-Cooking Equivalent $=$ Weight Used - (Pre-Cooking Weighs $!$ Post Cooking Weight) 
APPENDIX B

QUALITY ASSURANCE AND QUALITY CONTROL 


\section{APPENDIX B}

\section{QUALITY ASSURANCE AND QUALITY CONTROL}

A Work Plan describing all pertinent procedures and criteria was written before the start of the field- or laboratory-based project work. Adherence to the Work Plan was monitored by the Project Manager and the Battelle Ocean Sciences (BOS) Quality Assurance Unit. Data quality is defined by comparability, representativeness, completeness, accuracy, and precision in field and laboratory activities. Comparability between this project and earlier studies was ensured by using standard methods that were consistent with those used in other Battelle studies. Representativeness was addressed through the design of the field and analytical program, and by the proper preservation and storage of samples, to ensure that the samples analyzed accurately represent the materials collected. Completeness, defined as the measure of data collected versus the amount expected under ideal conditions, was based $100 \%$ on the numbers of fish collected. However, only 21 of the desired 25 fish were collected, and, per mutual agreement among the BOS, PNL, and EPA Project Managers, the field effort was terminated after the 21 fish had been collected. Accuracy and precision were ensured by processing a set of laboratory quality control (QC) samples, as discussed in the following sections.

\section{LABORATORYQC}

The laboratory QC program included the processing of one procedural blank, one matrix spike (MS), and one matrix-spike duplicate (MSD) sample with each batch of no more than 20 field samples. There was a total of five analytical batches of samples. The procedural blanks (containing all reagents used in sample processing, carried through all steps and treated as samples) were processed to ensure there were no significant levels of laboratory contamination (see Tables A.2 through A.5 in Appendix A). The MS and MSD samples (field samples amended with the 18 PCB congeners) were used to demonstrate laboratory accuracy and precision (Table B.1). Surrogate standard recoveries were monitored for every sample to provide data on the efficiency of the sample extraction and other sample-processing manipulations (Table B.2). Criteria goals for surrogate (every sample) and PCB analyte (MS and MSD samples) recoveries were between 50 and 150\%; precision in the duplicate analyses (MS/MSD) was to be a relative percent difference (\%RPD) of no more than $30 \%$; and analyte concentrations measured in the procedural blank were to be less than five times the method detection limit (MDL). 
A three-point calibration was analyzed on the analytical instrument (GC/ECD) before each batch of field samples. The three standard solutions in the three-point calibration included all PCB congeners, surrogate, and internal standard analytes, and covered the expected concentration range of the laboratory samples. The initial calibrations were determined by calculating the relative response factors (RRF) of each analyte, relative to the surrogate, for each of the three standards. For the calibration to be valid, the average relative standard deviation in the average RRF for the three concentration levels was to be less than $30 \%$ for every analyte. A midlevel calibration standard also was analyzed at least every 12 samples. The \%RPD between the RRF of the midlevel check and the average RRF determined from the initial calibration was to be less than $30 \%$ for every analyte. Any failure to meet calibration and other quality control criteria goals was brought to the attention of the Project Manager, who determined the appropriate action to be taken.

\section{SAMPLE AND DATA TRACKING}

Thorough sample-labeling, chain-of-custody, and log-in procedures were followed. During field collection, field/site forms were completed that included information such as numbers and types of fish collected, location, date, collection method, time, person(s) collecting, and other field observations. In the laboratory, sample-identification/log forms were completed as the individual fish (and subsamples from the fish) were given distinct identifications, and preprinted labels with the same sample identifications were affixed to the sample containers. This procedure created a link between the sample and the data recorded on all laboratory log forms. The sample identifications assigned in the laboratory also were recorded on chain-of-custody forms and were used to track the sample from preparation to final archiving. The samples were in the custody of the field personnel while in the field and during transport to the laboratory, and custody was relinquished to the Laboratory Sample Custodian at the laboratory. Sample storage location, date, and type of analysis also were recorded as the samples progressed through the laboratory. Samples released to other laboratory personnel for analysis were accompanied by sample-transfer documentation.

In the laboratory, all manipulations and processing of the samples were documented on laboratory record forms. Project number, date, and name of the person recording the information were included on the forms. The standard BOS laboratory forms used included forms to record sample identifications, extraction sample weight information, dry weight, lipid weight, spiking, sample cleanup/HPLC, and submission for instrumental analysis. Miscellaneous Documentation Forms were used to record information not covered by standard forms and to record other notable observations/events and deviations from protocol.

Documentation, Data Reduction, and Reporting 
All field and laboratory records were maintained on standard forms in three-ring binders. All data were recorded in ink; entries were signed and dated when entered; and any changes were initialed, dated, and explained. Any deviations from Standard Operating Procedures (SOP) or the Work Plan were documented, explained, and approved by the Project Manager. The possible impact of any such deviations on the data was determined by the Project Manager.

\section{Data Validation}

Data-validation procedures included checking for accuracy of transcription and calculation, reviewing for conformance with preestablished QC requirements, and evaluating for scientific validity. The Analytical Chemistry Task Leader and Project Manager reviewed the data to ensure conformation with the Work Plan.

\section{Performance and System Audits}

The BOS Quality Assurance Unit (QAU) was independent of all work activities pertaining to this study. The QAU monitored the project according to the Work Plan and to existing BOS SOPs to ensure the accuracy, integrity, and completeness of the data. QAU scope included a system inspection, performance and data audits, and document review.

\section{Corrective Action}

The Analytical Chemistry Task Leader, Project Manager, Laboratory Manager, and QAU monitored the activities described in this document. All documentation and data were reviewed, and deviations from the Work Plan were recorded. Appropriate corrective action to any identified problems or deviations was addressed by the Project Manager.

\section{QUALITY CONTROL RESULTS}

The laboratory quality control data are reported in Tables B.1 and B.2. The matrix-spike surrogate recoveries are reported in Table B.1, and the results are reported in Table B.2. Additionally, procedural-blank data are reported with each set of fish sample data (Tables A.2 through A.5 in Appendix A).

The procedural-blank data are reported in total nanograms. This value can be converted to nanograms per gram by dividing by the appropriate sample weight for comparison to fish sample concentrations. No PCB analytes were detected in the untreated fish batch. Low levels of $\mathrm{Cl}_{4}(44)$ and $\mathrm{Cl}_{7}(170)$ were detected in procedural blanks processed with treatment batches. However, these concentrations were below five times the MDL and were low relative to the concentrations determined in the fish. 
Average surrogate recoveries, by analytical batch, ranged from 66 to $87 \%$ for the five analytical batches of samples. Surrogate recoveries were slightly below the criteria goal of $50 \%$ for 4 of the 99 samples processed in this study, but this condition is not expected to have significantly affected the analytical data.

The precision in the MS/MSD analyses, represented by the \%RPD, was good with the exception of one sample. Matrix-spike sample J176MS, processed with the batch of deep-fried fish samples, appeared to suffer from mass discrimination as a result of poor autosampler sample injection onto the gas chromatograph. This incident was isolated and sample-specific, judging by the GC responses for the analytical standards and all other samples. It resulted in the progressively higher \%RPDs with increasing analyte molecular weight, and progressively lower analyte recoveries for JI76MS with increasing molecular weight. Matrix-spike duplicate sample JI77MSD (processed with JI76MS) yielded good recoveries, and other MS/MSD data were good. The MS/MSD recovery data are reported relative to the surrogate compound DBOFB and are not absolute recoveries, allowing a better assessment of the field sample analyte quantification. Absolute recoveries for the MS and MSD samples can be obtained by multiplying the percent recoveries reported by the recovery of the surrogate (see Table B.2) for the sample. There are some analyte-specific deviations from the recovery criteria goal of 50 to $150 \%$; however, these deviations are for analytes [particularly $\mathrm{Cl}_{5}$ (118), $\mathrm{Cl}_{6}$ (138), and $\left.\mathrm{Cl}_{6}(153)\right]$ that were present at high levels in the background sample (relative to the amount spiked into the MS/MSD samples), making the data for these particular analytes unsuitable for assessing accuracy and precision. 
TABLE B.1. Laboratory Quality Control Data--Matrix Spike Data

Battelle Ocean Sciences

Matrix Spike Recoveries - Pilot Study Batch

file: oc2
Created: GSO 08/13/91

Val idated:
PCB Concentration Changes in Cooked Seafood

Phose 1: Uinter Flounder, G1969-0005

Motrix Spike/Spike Dupl icate Percent Recovery Data
Sample Data in $\mathrm{ng} / \mathrm{g}$ Wet Weight

Bottelle Lab ID:

Met Meight:

WF21-T-UN

25.05

JG25MS

15.23

JG2GNSD

Semple 10

CL2(08)

HCB

CL3(18)

CL3(28)

CL4(52)

CL4(44)

CL4(66)

CLD(101)

A CHLORDANE

TRANSHOHACHLOR

PPODE

OPDDD

CL5(118)

PPDDD

OPDOT

CL6(153)

CL5(105)

PPDOT

CL6(138)

CL7(187)

CL6(128)

CL7(180)

CL7(170)

Clo(195)

Cl9(206)

CL.10(209)

$\begin{array}{rrrr}1.13 & 4.76 & 4.68 & 1.7 \\ 0.22 & 3.42 & 3.47 & 1.5 \\ 1.41 & 4.68 & 4.71 & 0.7 \\ 4.34 & 7.28 & 6.97 & 4.4 \\ 3.80 & 6.46 & 6.65 & 2.9 \\ 1.10 & 4.50 & 4.57 & 1.7 \\ 13.10 & 14.95 & 16.29 & 8.6 \\ 1.51 & 4.85 & 4.86 & 0.2 \\ 9.60 & 12.05 & 12.83 & 6.3 \\ 14.21 & 17.63 & 18.41 & 4.3 \\ \text { ND } & 4.42 & 4.18 & 5.5 \\ 6.17 & 8.90 & 9.27 & 4.1 \\ \text { ND } & 2.88 & 2.82 & 2.0 \\ 25.75 & 29.64 & 31.40 & 5.8 \\ 1.97 & 6.22 & 6.09 & 2.1 \\ 5.45 & 9.43 & 9.58 & 1.6 \\ 28.74 & 32.89 & 36.96 & 0.1 \\ 9.76 & 13.25 & 13.35 & 0.8 \\ \text { ND } & 9.03 & 8.64 & 4.4 \\ 27.40 & 31.94 & 33.67 & 5.3 \\ 3.61 & 6.39 & 6.72 & 5.1 \\ 5.11 & 7.70 & 8.29 & 7.4 \\ 7.05 & 9.77 & 11.14 & 13.1 \\ 5.29 & 0.13 & 8.34 & 2.6 \\ 0.80 & 3.94 & 3.96 & 0.6 \\ 0.60 & 3.61 & 3.68 & 1.9 \\ 0.33 & 3.42 & 3.35 & 2.1\end{array}$

MS/MSO Corrected for

Bockground in ng/g wet Weight

$\begin{array}{rr}\text { JG25MS } & \text { JG26MSD } \\ 15.23 & 15.04\end{array}$

$\begin{array}{ll}3.63 & 3.55 \\ 3.20 & 3.25 \\ 3.28 & 3.31 \\ 2.94 & 2.63 \\ 2.58 & 2.77 \\ 3.40 & 3.48 \\ 1.85 & 3.19 \\ 3.34 & 3.33 \\ .2 .45 & 3.23 \\ 3.42 & 4.20 \\ 4.42 & 4.18 \\ 2.73 & 3.10 \\ 2.88 & 2.82 \\ 3.89 & 5.65 \\ 4.25 & 4.13 \\ 3.99 & 4.14 \\ 4.16 & 6.23 \\ 3.48 & 3.59 \\ 9.03 & 8.64 \\ 4.54 & 6.27 \\ 2.78 & 3.11 \\ 2.59 & 3.18 \\ 2.72 & 4.09 \\ 2.84 & 3.05 \\ 3.13 & 3.16 \\ 3.01 & 3.08 \\ 3.10 & 3.03\end{array}$

$x$ Recovery of MS/MSD

Dota Background Corrected

JG25HS JG26HSD AVERAGE

$106.3 \quad 102.7 \quad 104.5$

$\begin{array}{lll}9.0 & 99.4 & 99.2\end{array}$

$\begin{array}{lll}95.9 & 95.7 & 95.8\end{array}$

$86.0 \quad 76.0 \quad 81.0$

$\begin{array}{lll}75.6 & 80.2 \quad 77.9\end{array}$

$\begin{array}{lll}99.6 & 100.5 & 100.1\end{array}$

$\begin{array}{lll}54.1 & 92.3 & 73.2\end{array}$

$\begin{array}{lll}103.3 & 101.8 & 102.6\end{array}$

$\begin{array}{lll}71.7 & 93.4 & 82.6\end{array}$

$\begin{array}{lll}105.7 & 128.2 \quad 116.9\end{array}$

$\begin{array}{lll}135.8 & 127.0 \quad 131.4\end{array}$

$83.9 \quad 94.1 \quad 89.0$

$88.9 \quad 86.1 \quad 87.5$

$\begin{array}{lll}113.2 & 162.6 & 137.9\end{array}$

$\begin{array}{lll}131.5 & 126.0 & 128.0\end{array}$

$\begin{array}{lll}123.3 & 126.4 & 124.8\end{array}$

$\begin{array}{lll}121.1 & 179.3 & 150.2\end{array}$

$\begin{array}{lll}102.0 & 103.7 & 102.9\end{array}$

$280.6 \quad 265.2 \quad 272.9$

$\begin{array}{lll}133.0 & 181.4 & 157.2\end{array}$

$80.9 \quad 89.6 \quad 85.2$

$75.9 \quad 92.1 \quad 64.0$

$\begin{array}{lll}79.6 & 118.2 & 98.9\end{array}$

$\begin{array}{lll}82.7 & 87.8 & 85.3\end{array}$

$91.8 \quad 91.3 \quad 91.5$

$89.9 \quad 90.8 \quad 90.4$

Percent Recovery $=($ Sample Bachground corrected ng/g $\bullet$ Sample g Wet Weight) $/$ Spike Amount 100 
Battelle Ocean Sciences

Matrix Spike Recoveries - Untreated Fish Botch file: ac2

Sample Dato in ng/g Wet Weight

Battelle Lab 10:

wet weight:

$$
\begin{array}{r}
\text { WF01-UN } \\
25.23
\end{array}
$$

JLITNS

20.38

JL 184SD

21.81

XRPD

Semple to

CL2(08)

HCB

CL3(18)

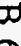

CL3(28)

CL4(52)
Creoted: GSO

Volidated:

CL4(66)

OPDDE

CLS(101)

A CHLORDAHE

TRANSHOWACHLOR

PPDDE

OPDDD

CLS(118)

PPDDD

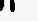

CL6(153)

CL5(105)

PPDDT

C(6) 138)

CL7(187)

CL6(128)

CL7(180)

CL7(170)

$C L 8(195)$

CL9(206)

CL10(209)

$\begin{array}{rrrr}0.49 & 3.76 & 3.37 & 10.4 \\ 0.07 & 2.78 & 2.54 & 9.1 \\ 0.23 & 3.50 & 3.24 & 7.6 \\ 0.40 & 3.35 & 3.03 & 10.1 \\ 0.48 & 3.57 & 3.25 & 9.1 \\ 0.25 & 2.96 & 2.75 & 7.5 \\ 0.30 & 3.82 & 3.50 & 8.6 \\ \text { ND } & 3.13 & 2.48 & 23.2 \\ 0.65 & 3.78 & 3.41 & 10.3 \\ 0.15 & 3.05 & 2.86 & 6.6 \\ 0.20 & 3.33 & 3.11 & 6.9 \\ 1.04 & 3.97 & 3.58 & 10.2 \\ \text { ND } & 2.70 & 2.76 & 2.1 \\ 0.95 & 4.43 & 4.01 & 9.8 \\ \text { ND } & 3.34 & 2.75 & 19.5 \\ \text { ND } & 3.01 & 2.87 & 4.6 \\ 1.69 & 5.59 & 4.80 & 15.1 \\ 0.16 & 3.09 & 3.10 & 0.5 \\ \text { ND } & 2.96 & 2.90 & 2.1 \\ 1.48 & 4.88 & 4.46 & 8.9 \\ 0.37 & 3.55 & 3.33 & 6.2 \\ \text { ND } & 3.10 & 3.04 & 2.1 \\ \text { O.48 } & 3.86 & 3.65 & 5.6 \\ 0.15 & 3.52 & 3.32 & 6.0 \\ \text { ND } & 3.43 & 3.35 & 2.5 \\ \text { ND } & 3.70 & 3.62 & 2.2 \\ \text { ND } & 3.76 & 3.68 & 2.1\end{array}$

PCB Concentrotion Changes in Cooked Seafood

Phase 1: Vinter Flounder, G1969-0005

Matrix Spike/Spike Duplicate Percent Recovery Dato

Percent Recovery $=($ Sample Background corrected ng/g $\bullet$ Sample g Het Weight $) /$ Spike Amount -100

MS/MSD Corrected for Bockground in ng/g Het Height

$$
\begin{array}{rr}
\text { J1TMS } & \mathrm{Jt} 18 \mathrm{HASO} \\
20.38 & 21.81
\end{array}
$$

$\begin{array}{ll}3.25 & 2.88 \\ 2.71 & 2.47 \\ 3.27 & 3.02 \\ 2.95 & 2.63 \\ 3.09 & 2.78 \\ 2.71 & 2.50 \\ 3.52 & 3.20 \\ 3.13 & 2.48 \\ 3.14 & 2.77 \\ 2.90 & 2.71 \\ 3.13 & 2.91 \\ 2.93 & 2.55 \\ 2.70 & 2.76 \\ 3.47 & 3.06 \\ 3.34 & 2.75 \\ 3.01 & 2.87 \\ 3.90 & 3.11 \\ 2.93 & 2.95 \\ 2.96 & 2.90 \\ 3.40 & 2.98 \\ 3.10 & 2.96 \\ 3.10 & 3.04 \\ 3.38 & 3.17 \\ 3.38 & 3.17 \\ 3.43 & 3.35 \\ 3.70 & 3.62 \\ 3.76 & 3.68\end{array}$

$X$ Recovery of MS/MSO Data Background Corrected

JL1TMS JLIBHSD AVERAGE $20.38 \quad 21.81$

$\begin{array}{lll}127.3 & 120.8 & 124.1 \\ 112.3 & 109.4 & 110.9 \\ 128.3 & 126.5 & 127.4 \\ 115.6 & 110.1 & 112.9 \\ 121.0 & 116.4 & 118.7 \\ 106.4 & 104.9 & 105.6 \\ 137.9 & 134.3 & 136.1 \\ 129.6 & 109.9 & 119.7 \\ 122.9 & 116.0 & 119.4 \\ 120.0 & 119.8 & 119.9 \\ 128.9 & 128.1 & 128.5 \\ 120.7 & 112.2 & 116.5 \\ 111.8 & 122.2 & 117.0 \\ 135.4 & 127.6 & 131.5 \\ 138.1 & 121.6 & 129.8 \\ 124.4 & 127.1 & 125.7 \\ 152.1 & 130.0 & 141.1 \\ 114.8 & 123.5 & 119.1 \\ 123.1 & 129.0 & 126.0 \\ 133.4 & 125.2 & 129.3 \\ 123.9 & 123.5 & 123.7 \\ 121.6 & 127.5 & 124.6 \\ 132.3 & 132.7 & 132.5 \\ 131.7 & 132.4 & 132.1 \\ 134.5 & 140.3 & 137.4 \\ 147.8 & 154.7 & 151.2 \\ 147.4 & 154.4 & 150.9\end{array}$


Battelle Oceen sciences

Matrix Spike Recoveries - Deep frled Fish Butch File: oc2
Creoted: GSD 06/13/91 Validated:
PCB Concentration changes in Cooked Seafood Phase 1: Uinter flounder. G1969-0005

Matrix Spike/Spike Duplicate Percent Recovery Dato
Somple Data in ng/g Wet Weight

\begin{tabular}{|c|c|c|c|c|}
\hline $\begin{array}{l}\text { Battelle Lab I0: } \\
\text { Wet Neight: }\end{array}$ & $\begin{array}{r}M F 20-1-11-D F \\
15.1\end{array}$ & $\begin{array}{r}31764 \mathrm{~S} \\
4.6\end{array}$ & $\begin{array}{r}\text { J177HSO } \\
4.6\end{array}$ & XRPD \\
\hline \multicolumn{5}{|l|}{ Sample to } \\
\hline $\operatorname{CL} 2(08)$ & 0.25 & 10.32 & 10.61 & 2.7 \\
\hline НСB & 0.06 & 9.20 & 9.62 & 4.4 \\
\hline $\operatorname{CL3}(18)$ & 0.85 & 10.14 & 11.22 & 10.1 \\
\hline $\operatorname{CL} 3(28)$ & 4.65 & 14.46 & 16.64 & 14.0 \\
\hline$C L 4(52)$ & 3.27 & 12.09 & 13.57 & 11.5 \\
\hline$C(4(46)$ & 1.05 & 10.22 & 12.74 & 21.9 \\
\hline$C L 4(66)$ & 14.53 & 21.46 & 32.06 & 39.7 \\
\hline OPDDE & NO & 7.98 & 10.04 & 22.9 \\
\hline CLS(101) & 14.74 & 17.72 & 27.51 & 43.3 \\
\hline a chlordane & 0.09 & 8.21 & 10.93 & 28.4 \\
\hline TRANSHONACHLOR & 0.24 & 8.46 & 19.52 & 30.7 \\
\hline PPDDE & 4.56 & 10.93 & 19.07 & 54.3 \\
\hline OPODD & 1.23 & 7.60 & 12.60 & 49.5 \\
\hline CL5(118) & 69.13 & 51.08 & 100.90 & 65.6 \\
\hline PPODD & 1.76 & 7.51 & 16.95 & 77.2 \\
\hline OPDot & 1.66 & 7.59 & 13.63 & 57.0 \\
\hline Cl6(153) & 66.94 & 47.20 & 101.99 & 73.5 \\
\hline CL5(105) & 13.33 & 15.36 & 29.01 & 61.6 \\
\hline PPDDT & 0.13 & 5.54 & 12.61 & 77.9 \\
\hline$C l 6(138)$ & 64.31 & 42.10 & 99.46 & 81.0 \\
\hline $\operatorname{cL7}(187)$ & 4.58 & 7.94 & 17.46 & 75.0 \\
\hline CL6(128) & 3.48 & 7.97 & 18.77 & 80.8 \\
\hline $\operatorname{cLT}(180)$ & 11.29 & 9.60 & 25.24 & 89.8 \\
\hline $\operatorname{cl}(170)$ & 7.33 & 8.29 & 23.47 & 95.6 \\
\hline CL8(195) & 0.46 & 5.02 & 13.95 & 94.2 \\
\hline CL9(206) & 0.29 & 4.29 & 11.78 & 93.2 \\
\hline$C L 10(209)$ & 0.10 & 4.59 & 11.90 & 88.7 \\
\hline
\end{tabular}

MS/MSO corrected for Background in ng/g Wet Weight

J1764S

JITHSD

$4.6 \quad 4.6$

$10.07 \quad 10.36$

$9.14 \quad 9.56$

$9.30 \quad 10.37$

$9.81 \quad 11.90$

$8.82 \quad 10.29$

$9.17 \quad 11.69$

$6.91 \quad 17.54$

$7.98 \quad 10.04$

$8.12 \quad 10.84$

$8.22 \quad 11.28$

$6.38 \quad 14.52$

$6.37 \quad 11.37$

$\begin{array}{rl}6.38 & 31.78\end{array}$

$5.74 \quad 15.18$

$5.93 \quad 11.97$

$\begin{array}{rl}-19.75 & 35.05\end{array}$

$2.03 \quad 15.69$

$5.41 \quad 12.49$

$-22.21 \quad 35.12$

$3.35 \quad 12.88$

$4.49 \quad 15.29$

$-1.69 \quad 13.95$

$0.96 \quad 16.14$

$4.56 \quad 13.50$

$3.99 \quad 11.48$

$4.49 \quad 11.80$

Percent Recovery $=$ (Semple Background corrected ng/g • Somple g Wet Height) / Spike Amount -100

$x$ Recovery of MS/MSD

Data Background Corrected

JITTMSTD AVERAGE

$4.6 \quad 4.6$

$\begin{array}{rrr}89.1 & 91.6 & 90.3 \\ 85.4 & 89.3 & 87.3 \\ 82.2 & 91.7 & 87.0 \\ 86.8 & 106.1 & 96.4 \\ 78.0 & 91.0 & 84.5 \\ 81.1 & 103.4 & 92.2 \\ 61.1 & 155.1 & 108.1 \\ 74.5 & 93.8 & 84.1 \\ 26.4 & 113.0 & 69.7 \\ 75.8 & 101.2 & 88.5 \\ 76.4 & 104.9 & 90.6 \\ 59.2 & 134.9 & 97.1 \\ 59.5 & 106.2 & 82.8 \\ 158.9 & 279.8 & 60.5 \\ 53.6 & 141.8 & 97.7 \\ 55.4 & 111.8 & 83.6 \\ 173.8 & 308.6 & 67.4 \\ 18.0 & 138.8 & 78.4 \\ 50.8 & 117.2 & 84.0 \\ 196.5 & 310.7 & 57.1 \\ 29.5 & 113.4 & 71.4 \\ 39.7 & 135.3 & 87.5 \\ -14.9 & 123.4 & 54.2 \\ 8.4 & 142.1 & 75.3 \\ 40.3 & 119.4 & 79.9 \\ 36.0 & 103.6 & 69.8 \\ 39.7 & 184.4 & 72.1\end{array}$


Bottelle ocean sciences

Matrix Spike Recoveries - Pan Fried Fish Botch File: oc2
Created: GSO 06/13/91 val idated:
PCB Concentration chenges in cooked Seefood

Phase 1: Winter flounder, G1969-0005

Matrix Spike/Splke Dupl icote Percent Recovery Data
Sample Dota in $\mathrm{ng} / \mathrm{g}$ Wet Weight

Battelle Lab 10: UF20-T-III-PF JIBOHS JIBIHSD XRPO Wet Neight:

$\mathbf{8 . 0}$

3.7

Sample 10

CL2(08)

HCB

CL3(18)

CL3(28)

CL4(52)

CL4(44)

CL4(66)

OPODE

CLS(101)

A CHLORDANE

TRAHSNOWACHLOR

PPODE

OPODD

CL5(118)

PPDDD

CL6(153)

CLS(105)

PPDDT

CL6(138)

Cl7(187)

CL6(128)

CL7(180)

CL7(170)

CL8(195)

CL9(206)

CL.10(209)

$\begin{array}{rrrr}\text { HO } & 15.05 & 13.42 & 11.5 \\ 0.13 & 13.31 & 11.94 & 10.9 \\ 1.65 & 15.97 & 13.67 & 15.5 \\ 6.86 & 25.73 & 25.06 & 2.6 \\ 5.58 & 21.42 & 18.65 & 13.8 \\ 1.29 & 16.50 & 15.30 & 7.6 \\ 23.85 & 50.59 & 47.44 & 6.4 \\ \text { ND } & 15.08 & 15.05 & 0.2 \\ 25.98 & 51.25 & 45.58 & 11.7 \\ 0.23 & 14.73 & 14.63 & 0.7 \\ 0.49 & 15.07 & 14.52 & 3.7 \\ 7.18 & 28.30 & 31.47 & 10.6 \\ 2.00 & 17.10 & 15.65 & 8.9 \\ 115.81 & 185.06 & 169.87 & 8.6 \\ 2.47 & 20.98 & 23.07 & 9.5 \\ 2.59 & 18.14 & 18.09 & 0.3 \\ 118.49 & 191.33 & 170.49 & 11.5 \\ 19.82 & 40.16 & 41.40 & 3.0 \\ \text { ND } & 14.82 & 16.13 & 0.5 \\ 107.38 & 171.54 & 156.55 & 9.1 \\ 7.56 & 25.31 & 23.31 & 8.2 \\ 5.06 & 24.42 & 24.33 & 0.4 \\ 18.28 & 40.89 & 39.89 & 2.5 \\ 12.24 & 33.05 & 31.28 & 5.5 \\ 0.68 & 16.54 & 15.09 & 9.2 \\ 0.37 & 14.54 & 12.98 & 11.3 \\ 0.10 & 14.53 & 12.81 & 12.6\end{array}$

MS/MSD Corrected for

Background in ng/g Wet Weight

$\begin{array}{rr}\text { JIBOHS } & \text { J181MSD } \\ 3.5 & 3.7\end{array}$

$15.05 \quad 13.42$

$\begin{array}{ll}13.18 & 11.81 \\ 14.32 & 12.02\end{array}$

$10.87 \quad 18.20$

$15.84 \quad 13.07$

$15.21 \quad 14.01$

$26.75 \quad 23.60$

$15.08 \quad 15.05$

$25.27 \quad 19.60$

$14.51 \quad 14.40$

$14.58 \quad 14.03$

$21.13 \quad 24.30$

$15.10 \quad 13.65$

$69.25 \quad 54.05$

$18.51 \quad 20.60$

$15.55 \quad 15.50$

$72.84 \quad 51.99$

$20.35 \quad 21.58$

$14.02 \quad 16.13$

$64.16 \quad 49.17$

$17.76 \quad 15.75$

$19.36 \quad 19.27$

$22.61 \quad 21.61$

$20.81 \quad 19.04$

$15.86 \quad 14.41$

$14.17 \quad 12.62$

$14.43 \quad 12.71$ $x$ Recovery of MS/MSO Dota Background Corrected

JIBOMS JIBIMSD AVERAGE

$\begin{array}{ll}3.5 & 3.7\end{array}$

$101.3 \quad 95.5 \quad 98.4$

$\begin{array}{lll}93.7 & 88.7 & 91.2\end{array}$

$\begin{array}{lll}96.4 & 85.5 & 90.9\end{array}$

$\begin{array}{lll}127.0 & 129.5 & 128.3\end{array}$

$106.6 \quad 93.0 \quad 99.8$

$\begin{array}{lll}102.4 & 99.7 \quad 101.0\end{array}$

$\begin{array}{lll}180.0 & 167.9 & 174.0\end{array}$

$107.1 \quad 113.0 \quad 110.1$

$\begin{array}{lll}170.1 & 139.5 & 154.8\end{array}$

$103.1 \quad 108.2 \quad 105.6$

$103.1 \quad 104.9 \quad 104.0$

$\begin{array}{lll}149.4 & 181.6 & 165.5\end{array}$

$107.3 \quad 102.6 \quad 104.9$

$463.9 \quad 382.8-423.3$

$\begin{array}{lll}131.6 & 154.8 & 143.2\end{array}$

$\begin{array}{lll}110.5 & 116.4 & 113.5\end{array}$

$\begin{array}{lll}487.9 & 368.2 & 428.1\end{array}$

$\begin{array}{lll}136.9 & 153.6 & 145.2\end{array}$

$\begin{array}{lll}105.8 & 121.8 & 113.8\end{array}$

$\begin{array}{lll}431.9 & 349.9 & 390.9\end{array}$

$118.9 \quad 111.6 \quad 115.2$

$130.3 \quad 137.1 \quad 133.7$

$152.1 \quad 153.8 \quad 153.0$

$\begin{array}{lll}139.4 & 134.8 & 137.1\end{array}$

$106.8 \quad 102.5 \quad 104.6$

$97.2 \quad 91.5 \quad 94.4$

$\begin{array}{lll}97.1 & 90.4 & 93.8\end{array}$

Percent Recovery = (Somple Background corrected $n g / g *$ Sample g Wet Weight) / Spike Amount * 100 


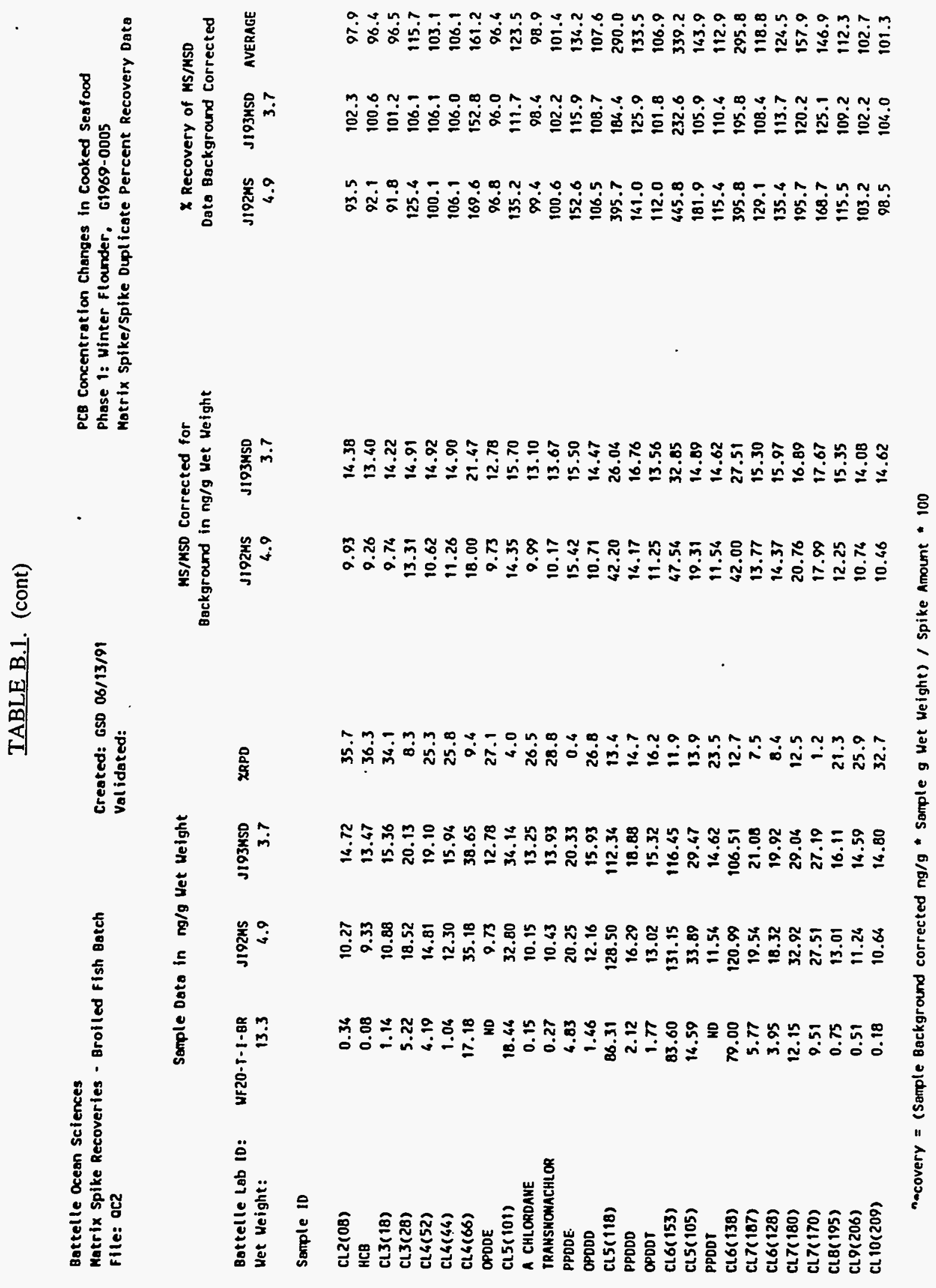

B. 9 
TABLE B.2. Laboratory Quality Control Data--Surrogate Recovery Data

Barzelle Ocean Sciences

Surrogate Recoveries - Pilot study Batch file: OC1

Created: CSD 06/13/91

Validared:

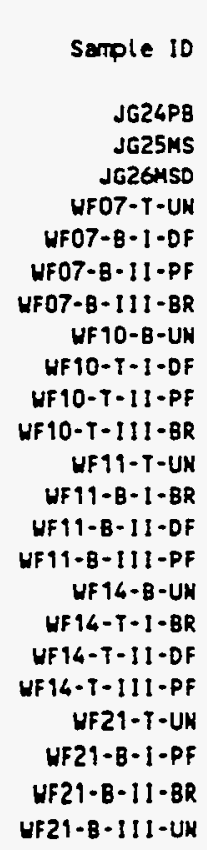

\% Recovery
D8OFB

91.4
93.0
88.3
86.3
93.1
83.3
83.3
79.8
92.9
93.5
86.8
80.0
88.2
92.0
84.0
87.9
92.0
91.0
81.7
84.9
86.7
79.7
86.5
87.2
Average:

Battelle Qcean Sciences

Surrogate Recoveries - Untreated fish Batch

PCB Concentration Changes in Cooked Seafood

Phese 1: Winter Flander, 61969-0005
PCB Concentration Changes in Cooked Sesfood Phase 1: Winter Flander, 61969-0005

\begin{tabular}{|c|c|}
\hline Sample 10 & $\begin{array}{c}\approx \text { Recovery } \\
\text { DBOFB }\end{array}$ \\
\hline$J L 16 P B$ & 65.2 \\
\hline Jl17MS & 67.4 \\
\hline JL18MSO & 68.4 \\
\hline WFOI-UH & 56.8 \\
\hline WFO2-UN & 66.9 \\
\hline WFO3-UN & 60.5 \\
\hline WFOG-UN & 74.6 \\
\hline HF05-UN & 71.1 \\
\hline WFOS-UN & 70.6 \\
\hline HFOS-UH & 79.5 \\
\hline WF09-UN & 67.5 \\
\hline WF12-UK & 77.7 \\
\hline UF13-UN & 67.9 \\
\hline UF 15-UN & 65.5 \\
\hline WF16-UN & 59.2 \\
\hline UF $17-U N$ & 67.3 \\
\hline WF 18-UN & 61.4 \\
\hline UF 19-UN & 78.0 \\
\hline WF 20-UN & 78.8 \\
\hline & 68.9 \\
\hline
\end{tabular}


TABLE B.2. (cont)

Battelle Ocean Sciences

Surrogate Recoveries - Deep fried Fish Batch File: oci

Crested: GSO 06/13/91

validated:

Sample 10

$$
\begin{aligned}
& \text { JI75PB } \\
& \text { JI76HS } \\
& \text { J177MSO }
\end{aligned}
$$

\begin{tabular}{|c|c|}
\hline & X Recovery \\
\hline Sample 10 & DBOFB \\
\hline J179PB & 87.5 \\
\hline J180MS & 85.2 \\
\hline JIBIMSD & 90.7 \\
\hline WFO1-B-I1-PF & 75.2 \\
\hline $\mathrm{HFO2-T-1!1-PF}$ & 58.0 \\
\hline$W F 03-B-1-P F$ & 85.8 \\
\hline HFO4-T-II-PF & 84.0 \\
\hline HFO5-B-III-PF & 58.4 \\
\hline WF06-T-1-PF & 96.9 \\
\hline WFOB-T-IIII-PF & 60.2 \\
\hline$W F 09-B=1-P F$ & 72.2 \\
\hline WF 12-T-I-PF & 62.5 \\
\hline$W F\{3-B-I I-P F$ & 72.5 \\
\hline$W F 15 \cdot B-I-P F$ & 90.3 \\
\hline WF 16-T-II-PF & 89.6 \\
\hline UF $17-B-11 I-P F$ & 52.9 \\
\hline HF18-T-1-PF & 55.3 \\
\hline$W F 19-8-11-P F$ & 74.1 \\
\hline$W F 20 \cdot T \cdot 11 I \cdot P F$ & 69.8 \\
\hline Average: & 74.8 \\
\hline
\end{tabular}

PCB Concentration Changes in cooked Seafood Phase 1: Vinter-flounder, 61989-0005
Average:
6.1

Battelle Ocean Seiences

Surrogate Recoveries - Pan Fried Fish Batch

PCB Concentration Changes in cooked seafood

Phase 1: Winter flounder, G1969-0005

B.11 
Batzelle Ocean Sciences

Surrogate Recoveries - Broiled fish Batch

File: oCI

Created: GSO 06/13/99

Val idated:
PCB Concentration Chenges in Cooked Seafood

Phase 1: Winter Flounder, 61969-0005

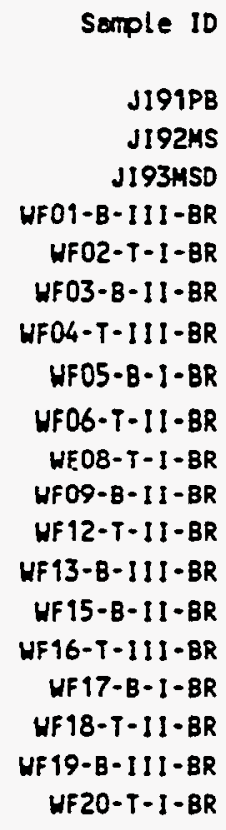

Average:
X Recovery

DBOFB

77.8

79.5

74.5

82.6

56.8

87.2

78.0

58.7

89.9

63.0

88.9

64.5

69.7

88.5

83.7

59.3

62.1

82.5

$\pi .8$

74.8 


\section{DISTRIBUTION}

No. of

Copies

\section{OFFSITE}

12 DOE/Office of Scientific and Technical Information

13 J. Moya (10)

U.S. Environmental Protection Agency 401 M Street SW

Washington, DC 20460

B. Boczwara

Battelle Ocean Sciences 397 Washington Street Duxbury, MA 02332

G. Durell

Battelle Ocean Sciences 397 Washington Street

Duxbury, MA 02332

A. M. Spellacy

Battelle Ocean Sciences 397 Washington Street Duxbury, MA 02332
No of

Copies

\section{ONSITE}

24 Pacific Northwest Laboratory

C. A. Brandt

K6-84

M. L. Blanton

K6-75

D. D. Dauble

K6-85

J. G. Droppo

K6-80

D. A. Neitzel

G. W. Patton

T. M. Poston (10)

D. L. Strenge

K6-85

K6-75

K6-75

Publishing Coordination

Technical Report Files (5)

K3-54

K1-06

Routing

R. W. Bryce

K9-34

R. M. Ecker

S. A. Rawson

SEQUIM

R. L. Skaggs

K9-34

P. C. Hays (last)

K6-91

K9-41 